Review

\title{
Aquatic Ecological Risk of Heavy-Metal Pollution Associated with Degraded Mining Landscapes of the Southern Africa River Basins: A Review
}

\author{
Kennedy O. Ouma ${ }^{1,2, * \mathbb{C}}$, Agabu Shane ${ }^{3}$ and Stephen Syampungani ${ }^{1}$ \\ 1 Department of Plant and Environmental Sciences, School of Natural Resources, The Copperbelt University, \\ Kitwe P.O. Box 21692, Zambia; syampungani@cbu.ac.zm or ssyampungani@yahoo.com \\ 2 Africa Centre of Excellence in Sustainable Mining, The Copperbelt University, Kitwe P.O. Box 21692, Zambia \\ 3 Department of Mining Engineering, School of Mines and Mineral Sciences, The Copperbelt University, \\ Kitwe P.O. Box 21692, Zambia; agabu.shane@cbu.ac.zm or agabushane@yahoo.com \\ * Correspondence: kennedy.ouma@cbu.ac.zm or kenochieng8477@gmail.com
}

check for

updates

Citation: Ouma, K.O.; Shane, A.; Syampungani, S. Aquatic Ecological Risk of Heavy-Metal Pollution Associated with Degraded Mining Landscapes of the Southern Africa River Basins: A Review. Minerals 2022, 12, 225. https://doi.org/ $10.3390 / \min 12020225$

Academic Editors: Benoît Plante,

Thomas Pabst and David Wilson

Received: 22 October 2021

Accepted: 30 November 2021

Published: 10 February 2022

Publisher's Note: MDPI stays neutral with regard to jurisdictional claims in published maps and institutional affiliations.

Copyright: (c) 2022 by the authors. Licensee MDPI, Basel, Switzerland. This article is an open access article distributed under the terms and conditions of the Creative Commons Attribution (CC BY) license (https:// creativecommons.org/licenses/by/ $4.0 /)$.

\begin{abstract}
Africa accounts for nearly 30\% of the discovered world's mineral reserves, with half of the world's platinum group metals deposits, $36 \%$ of gold, and $20 \%$ of cobalt being in Southern Africa (SA). The intensification of heavy-metal production in the SA region has exacerbated negative human and environmental health impacts. In recent years, mining waste generated from industrial and artisanal mining has significantly affected the ecological integrity of SA aquatic ecosystems due to the accelerated introduction and deposition of heavy metals. However, the extent to which heavy-metal pollution associated with mining has impacted the aquatic ecosystems has not been adequately documented, particularly during bioassessments. This review explores the current aquatic ecological impacts on the heavily mined river basins of SA. It also discusses the approaches to assessing the ecological risks, inherent challenges, and potential for developing an integrated ecological risk assessment protocol for aquatic systems in the region. Progress has been made in developing rapid bioassessment schemes (RBS) for SA aquatic ecosystems. Nevertheless, method integration, which also involves heavy-metal pollution monitoring and molecular technology, is necessary to overcome the current challenges of the standardisation of RBS protocols. Citizenry science will also encourage community and stakeholder involvement in sustainable environmental management in SA.
\end{abstract}

Keywords: aquatic ecosystems; bioassessment; bioindicator; ecological risk assessment; heavy-metal pollution; Southern Africa; mining and processing; rapid bioassessment schemes

\section{Introduction}

Southern Africa (SA) is rich in large river basin networks, from the over 1.4 million $\mathrm{km}^{2}$ Zambezi River Basin in the upper parts and extending further to the 0.4 million $\mathrm{km}^{2}$ Limpopo and 0.9 million $\mathrm{km}^{2}$ Orange River Basin systems southwards [1-3]. Given that most SA river basins hold vast mineral deposits, the mining waste generated by artisanal and mechanised mining industries has significantly affected the health of its aquatic ecosystems [4-8]. Nevertheless, progress has been made in assessing the ecological risks of mining and mineral processing to characterise and manage geogenic and anthropic aquatic pollution in SA [9-12]. Ecological risk assessment (ERA) principally employs biological organisms to detect, evaluate, and predict ecological impacts of physical, chemical, and biological environmental changes in ecosystems. ERA comprises a logical process of assessing the occurrence or possibility of adverse ecological impacts from exposure to one or more undesired ecological effects $[13,14]$. The process incorporates problem formulation, exposure impact, effect analysis, risk characterisation, and risk-driven management decision-making [14]. Therefore, ERA provides a comprehensive mechanism for determining, monitoring, and sustainably managing ecosystem health and integrity. 
Aquatic ecosystem health and integrity is critical, considering their role in providing physical and biologically mediated ecosystem goods and services $[15,16]$. Aquatic systems are environmental buffers to human health; they reduce the risks associated with pollutants and pathogenic microorganisms $[17,18]$ that would otherwise impact human health. Therefore, monitoring natural and anthropic risks to these ecosystems using ecological indicators must be a priority for sustainable environmental management. Karr [19] described several ecological indicators (EIs) used to assess ecosystem stressors (e.g., contaminants), the exposure magnitude (e.g., pollutant concentration and habitat alteration), and response dynamics (e.g., community metrics and thermodynamics). Suitable EIs should be "measurable, integrative, ecologically and socially relevant, interpretable, cost-effective, anticipatory, collected at appropriate geographic and temporal scales, and able to detect trends" [19]. EIs must respond to multiple stressors and provide quantitative, comparable, and statistically reliable information based on sound ecological principles [20].

Conventional physical and chemical monitoring methods have been primarily and widely applied to evaluate the integrity of aquatic environments [21,22]. Over time, techniques have been developed, tested, and improved to increase the precision in monitoring and evaluating ecosystem health and ERA [23-25]. Besides physicochemical monitoring, biomonitoring can also be adopted during the ERA of aquatic systems (e.g., diversity and biotic indices and multimetric and multivariate techniques). Biomonitoring, including the application of functional feeding groups (FFGs) and multiple biological trait (e.g., molecular) characterisation, is being adopted as a complementary biomonitoring approach [26,27]. This review dwells on the current approaches to assessing the ecological risks to lotic systems in mining basins of SA from heavy-metal mining and processing. We also explore the inherent challenges and potential for developing and integrating an ERA protocol for the bioassessment of SA mining basins' aquatic systems.

\section{River Basins of Southern Africa and Environmental Threats}

Africa's metallic and non-metallic mineral enrichment accounts for nearly $30 \%$ of the discovered Earth's reserves [28]. For instance, 55\% of the global diamond production comes from the Democratic Republic of Congo (DRC) and Botswana. Gold mining in Africa contributes to $60 \%$ of her mineral production and $22 \%$ of the Earth's total gold [29]. Despite this substantial endowment, Africa's mineral production accounts for a dismal $5.5 \%$ of the global total, only second to Asia with 58.3\% [30]. There are significant mineral deposits in SA and an extended exploration and exploitation history [4,31]. South Africa, in particular, contributes up to $50 \%$ of SA minerals [28]. In 2018, the region produced approximately $20.2 \%$ of the sub-Saharan Africa (SSA) minerals, principally as iron and ferro alloys (9.7\%), nonferrous metals $(0.6 \%)$, precious metals $(0.1 \%)$, and industrial minerals $(9.8 \%)$ [30]. There are also significant quantities of mineral fuel deposits, including coal (e.g., in Mozambique, South Africa, Zimbabwe, and Zambia); oil (e.g., in Angola and DRC); and uranium (e.g., in Namibia and South Africa) [30]. The fuels and mineral exports account for over $58 \%$ of Africa's trade exchange [28].

Given the enormous mineral potential in SA, revenue from the mining industry has soared in recent years [32-34]. For instance, in 2018, South Africa produced over 380 million metric tons of mineral fuels, iron and ferro alloys, and ferrous metals of US $\$ 120$ billion market value [30]. However, the intensification of mineral production in SA has exacerbated negative human and environmental health impacts [35]. The adverse effects include water pollution [36], atmospheric air contamination [37], land degradation [38], and threats to biodiversity [39,40] and animal and human health [41] and the disruption of ecosystems [8]. Rivers have been the most affected due to their lotic nature, hence receiving anthropicderived effluents from adjacent ecosystems within mining catchments [12,42-44]. Detailed accounts of the vulnerability of lotic ecosystems to large-scale pollution sources are widely available in the published literature and scientific-based information repositories [45-47]. 


\subsection{Southern Africa River Basin Systems}

The Southern African Development Community (SADC) block comprises 16 member states, including neighbouring region members such as Tanzania (Eastern Africa) and DRC (Central Africa), on a total land area of 9,779,742 $\mathrm{km}^{2}$ inhabited by over 345 million people as of 2018 [48,49]. About $25 \%$ of the total land is suitable for agricultural production [50]. The Southern Africa region of SADC has 12 major transboundary river basins that extend from the 1.4 million $\mathrm{km}^{2}$ of the Zambezi Basin, south of the vast Congo Basin and the Limpopo Basin draining over $400,000 \mathrm{~km}^{2}$ of the land area to the $900,000 \mathrm{~km}^{2}$ of the Orange-Senqu Basin to the south (Figure 1). With a 1.39-million $\mathrm{km}^{2}$ land area, the Zambezi Basin transverses eight SADC states, where up to $70 \%$ transboundary water resources sharing occurs.

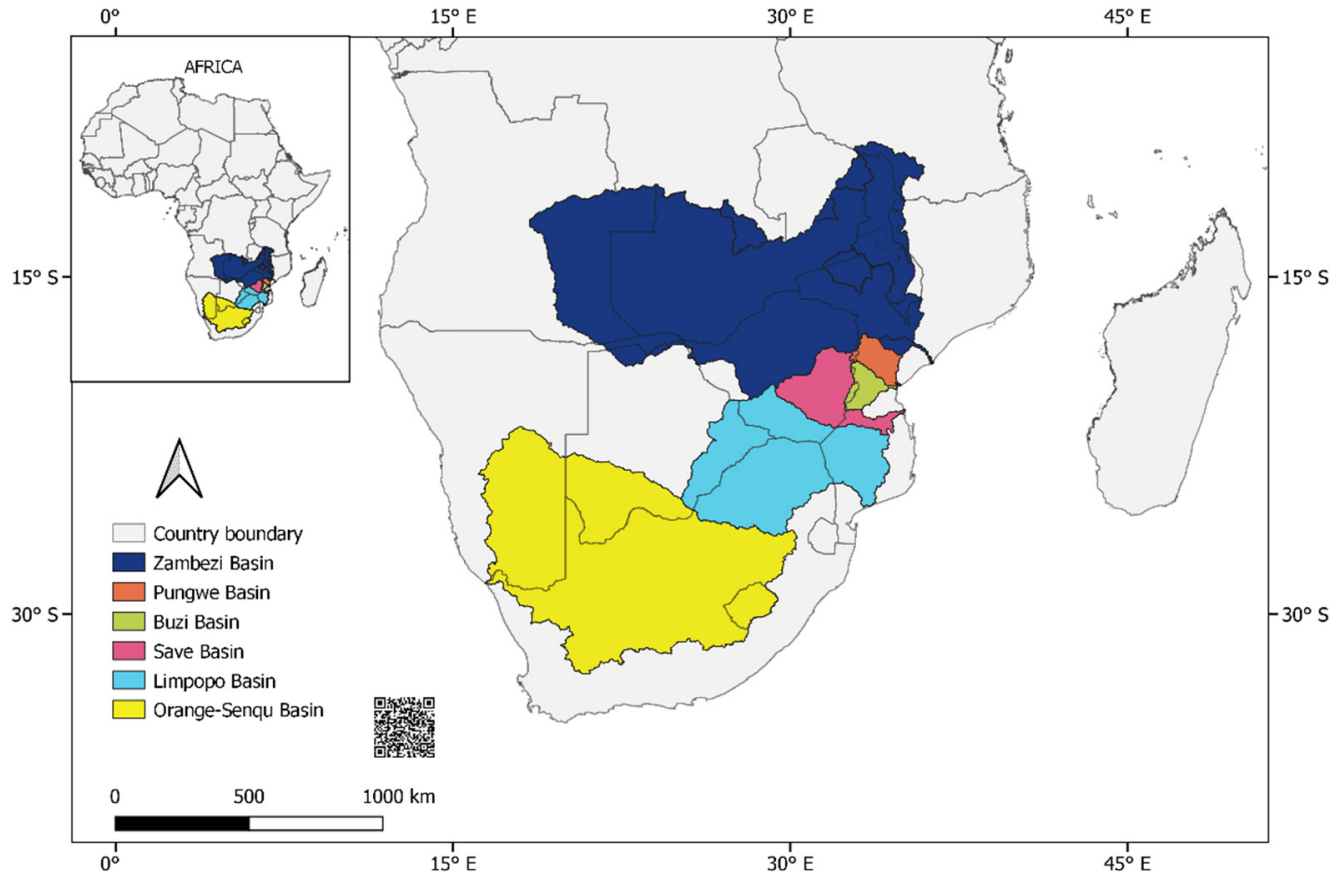

Figure 1. The river basins of Southern Africa threatened by aquatic pollution from heavy-metal mining and processing (Map shapefiles from FAO GeoNetwork [51]).

The SA basins face similar environmental challenges to most river basins worldwide. In particular, rapid human population increase and faster industrial development have exacerbated the impacts of climate change, causing extreme changes in basin hydrology; accelerating land degradation, agroindustrial (water, air, and soil) pollution; and biodiversity loss [3,49]. At least six basins (Zambezi, Pungwe, Buzi, Limpopo, Save, and Orange-senqu), with a total drainage area of 6.88 million $\mathrm{km}^{2}$ ( $88.1 \%$ of the SADC land area), have significant mining pollution among the environmental threats (Table 1). Over 158.1 million people across the seven basins comprise at least $45.8 \%$ of the SA population (2018 statistics).

\subsection{Environmental Threats to SA River Basins}

Like river basins elsewhere, the SA basins' environmental threats result from natural and anthropic pressures (Table 1). Environmental degradation, riparian population growth, and impacts from climate change and extreme hydrological events have caused alarming alterations to the basins' ecosystem functioning. The environmental presence and persistence of pollution elements (contaminants), either in physical, chemical, biological, or energy forms, harm biodiversity, are hazards to human and animal health, and deter ecosystem processes and services. Elevated levels of environmental contaminants increase the probability of environmental pollution [52], which, if uncontrolled, can cause irreversible damages and alterations to ecosystem functionality and service delivery. The point and 
diffuse sources of surface water pollution in SA include agroindustrial effluents, mining waste, atmospheric fallout, and e-waste recycling [45,53-56]. However, this review focuses mainly on the human-mediated pollution of aquatic systems from metal and industrial mineral mining, knowing that mining is a critical economic activity in SA [28].

\subsubsection{Aquatic Heavy-Metal Pollution}

Zambezi Basin

The widely studied 1.4-million $\mathrm{km}^{2}$ Zambezi Basin, shared by at least eight SADC states (Figure 1), endowed with minerals, is the largest in SA, implying significant environmental impacts from agriculture, industrial development, population growth, and natural resource utilisation [1,57]. In the arid Gruben region of Namibia, there was pollution of the Gruben River water flowing through copper mining spoil heaps, releasing $94.7 \%$ $\mathrm{Cu}\left(36 \mathrm{mg} \mathrm{L}^{-1}\right)$ and $90.5 \% \mathrm{Ni}\left(35 \mathrm{mg} \mathrm{L}^{-1}\right)$ and high $\mathrm{Cu}$ concentrations $\left(10,500 \mathrm{mg} \mathrm{L}^{-1}\right)$ in suspended sediments during episodic flows [58]. The surface waters of the "Yellow Jacket" (from Fe-hydroxysulphate precipitation) and Mazowe rivers in Zimbabwe have been observed to be highly acidic $(\mathrm{pH}<2)$ following contamination by outflows from the Iron Duke pyrite mine containing Fe; Fe alloys (Co and $\mathrm{Ni})$; and nonferrous metals $(\mathrm{Cu}$, $\mathrm{Pb}$, and $\mathrm{Zn}$ ) and sulphates [59]. Similarly, Love et al. [60] emphasised the role of mineral ore geochemistry and mineral processing technology in accelerating acid mine drainage formation, cyanide $(\mathrm{CN})$ formation, and the production of heavy-metal contaminants from waste rocks and slimes in the Zimbabwean Zambezi Basin. These groups of pollutants impact negatively aquatic biota communities (e.g., microbes, macroinvertebrates, fish, and macrophytes) $[60,61]$.

Ikenaka et al. [62] clustered heavy-metal pollution in Zambia based on the pollution intensity, with Kabwe and Copperbelt dominating. In Kabwe, Cu, Pb, Zn, Cd, and As release from smelter processing has caused soil and atmospheric contamination [63-65]. Surface runoff, leaching from the slag heaps, senescing metallophyte vegetation, and atmospheric fallout further deposit the metal contaminants into surface water drainage systems, resulting in aquatic pollution.

The Kafue River Basin, occupying about 20\% $\left(743,000 \mathrm{~km}^{2}\right)$ of Zambia's land area, drains the Copperbelt Province, also heavily impacted by mining waste pollution [38,66,67]. The waste effluents pose potentially adverse ecological risks to aquatic biota and human health [66]. The water and sediment pollution of the Kafue River, mainly by $\mathrm{Cu}, \mathrm{Co}, \mathrm{Cr}, \mathrm{Pb}$, and $\mathrm{Cd}$, significantly increases downstream in an alternate sink-source-sink pattern due to remobilisation and $\mathrm{pH}$ fluctuations, especially in the Kabwe transect [61,62]. Observable inputs of $\mathrm{Cu}$ and $\mathrm{Co}$ in bed sediments of the Mushishima Stream from HM processing plants and tailings in Chingola deserve attention to alleviate the potential environmental and health risks [59]. In Kitwe, aquatic HM contaminants originate from the Uchi Mine tailings, Nkana smelter, and the famous "Black Mountain" slag dumps in the town's industrial area into the aquatic system via leaching, precipitation, and overland flow [66].

$\mathrm{M}^{\prime}$ kandawire et al. [12] detailed the HM aquatic sediment pollution assessment of Kafue River and indicated high values for $\mathrm{As}, \mathrm{Co}$, and $\mathrm{Mn}$ and extreme enrichment with $\mathrm{Cu}$ within the industrial mining areas of the Copperbelt. The risk indices (RI) of the heavy metal pollution in the Kafue River were notably very high (RI > 600) across three seasonal transitions (warm-rainy, dry-cold, and dry-hot) in Chililabombwe and Chingola Districts, where industrial mining is predominant. In the Kafue area, the Kafue flats, however, serve as sinks of HM species, as reflected by the exceptionally low RI $(<150)$ values [68-70]. Since wetlands absorb large amounts of contaminants, this observation should be a concern to environmentalists and wildlife managers due to the likely increased risks during changes in the water chemistry and subsurface seepage that may cause HM release [71]. High levels of $\mathrm{Pb} \mathrm{mg} / \mathrm{kg}$ dry weight (DW) have been observed in wildlife (a semiaquatic grazer antelope, the Kafue lechwe, 16-18; Tilapia and African catfish, 23-33; commonly grazed grass, Echinochloa sp. 26-48) of the Lochnivar and Blue Lagoon National Parks in Kafue flats, thereby posing a health risk to higher trophic organisms $[12,72,73]$. 
Pungwe, Buzi, and Save Basins

The three basins cumulatively draining a basin area of $172,570 \mathrm{~km}^{2}$ are shared between Mozambique and Zimbabwe, with the main tributaries originating from Zimbabwe (Figure 1). Artisanal alluvial gold mining is predominantly informal across the subregions. For instance, in the Mozambique Pungwe Basin, over $90 \%$ of gold production comes from a long history of artisanal and small-scale mining (ASM) [74]. The sector employs over 20,000 people in Central Mozambique and produces nearly $600 \mathrm{~kg}$ of gold annually [75]. Over 500,000 miners earned income from ASM in Zimbabwe, contributing almost 50\% to the foreign earnings in 2016 [76]. However, uncontrolled ASM of gold and diamonds in the three basins exposes the surface waters to siltation, $\mathrm{Hg}, \mathrm{CN}$, and As contamination [77] and environmental degradation $[41,78]$. Such is the human health and environmental threats from unregulated gold prospecting in the Manica Province of Mozambique due to increased $\mathrm{Hg}$ amalgamation and $\mathrm{CN}$ toxicity [74,79]. Turbid water from suspended sediment and heavy-metal contaminants in transit from artisanal gold and diamond mining areas characterise River Buzi and its two major tributaries, Revue and Lucite [80,81].

Save River, a key source of drinking water for the riparian community, forms the primary drainage system for the Save Basin. In Zimbabwe's Buhera District of the Save Basin, phosphate rock (fluoroapatite) mining pollutes the surface water and sediment with $\mathrm{Cu}, \mathrm{Pb}, \mathrm{Co}, \mathrm{Ni}, \mathrm{Zn}, \mathrm{Cd}$, and Tn via weathering and dissolution of metal-hosting heavy metals [82]. Since alkaline rock bedloads adsorb mineral pollutants, they act as repositories forming a potential source of stream water pollution in the future [83,84]. Diamond mining in the Marange-Odzi Region releases high Fe, Ni, and $\mathrm{Cr}$ from ferro-silicon (FeSi) sand used during extraction into the Save-Odzi River with potential carcinogenic $(\mathrm{Cr}$ and $\mathrm{Ni}$ ) and $\mathrm{Fe}$ poisoning effects to consumers among the many environmental impacts to the basin [85].

Limpopo Basin

The 408,000 km² Limpopo Basin transcends ecologically important conservation zones of high biodiversity and supports a sizeable rural-urban population and farming communities. Mining and mineral processing in the basin contributes to physical and chemical environmental degradation, acid mine drainage, metal toxicity, erosion, and sedimentation $[46,86]$. The mining pollution threat has extended into aquatic systems of protected areas in the basin, e.g., South Africa's 2 million ha Kruger National Park [87]. In the Blyde and Steelport tributaries of the Olifants River, high $\mathrm{mg} \mathrm{L}^{-1} \mathrm{Fe}(0.01-0.4), \mathrm{Ni}(0.03-0.14)$, and $\mathrm{Zn}(0.004-0.054)$ in the surface water coupled with elevated $\mathrm{mg} \mathrm{kg}^{-1}$ sediment concentrations for $\mathrm{As}, \mathrm{Cr}, \mathrm{Fe}, \mathrm{Mn}, \mathrm{Ni}, \mathrm{Pb}$, and $\mathrm{Zn}$, indicated high metal enrichment [88]. Similarly, in Mvudi River of the lower Limpopo Basin, average concentrations of HM contaminants in $\mathrm{mg} \mathrm{L}^{-1}$ water $(\mathrm{Pb}, 0.287 ; \mathrm{Al}, 0.602 ; \mathrm{Fe}, 0.947 ; \mathrm{Mn}, 0.202 ; \mathrm{Cr}, 0.406)$ and $\mathrm{mg} \mathrm{kg}^{-1}$ sediments (Cr, 0.115; Cu, 0.701) surpassed the recommended South African/WHO guidelines for potable water $[89,90]$. These contaminants pose potential aquatic and human health risks to riparian water resource users [91].

Wolmarans et al. [92] affirmed the deteriorating condition of the Olifants River system. Out of 35 macroinvertebrate taxa sampled, only seven were highly sensitive to pollution. Additionally, Marr et al. [86] and Addo-Bediako et al. [91] noted that the consumption of Ba, $\mathrm{Co}, \mathrm{Cr}, \mathrm{Sb}, \mathrm{Pb}$, and $\mathrm{V}$ metal-contaminated tilapia and catfish from surface waters in the basin expose humans to health risks. In Dzindi River, the $\mathrm{mg} \mathrm{L}^{-1}$ heavy-metal contaminations from Fe (1.33), $\mathrm{Al}$ (0.3), $\mathrm{Mn}$ (0.15), $\mathrm{Zn}$ (0.10), $\mathrm{Cr}$ (0.06), $\mathrm{Cu}(0.05)$, and $\mathrm{Pb}(0.03)$ revealed probable health risks from drinking water use without pre-treatment [93]. In the Mkuvisi River in Harare, Zimbabwe, increased Fe, $\mathrm{Cr}, \mathrm{Cu}$, and $\mathrm{Zn}$ pollution from industrial and municipal waste effluents caused a sharp decline in macroinvertebrate taxa. The South African Scoring System (SASS-4) for the aquatic habitat assessment average score per taxon (ASPT) ranged from 2.74 (poor) to 3.61 (fair) for Mkuvisi River, indicating negative impacts on the aquatic biodiversity [94]. Additionally, the persistence of high Pb levels in sewage effluents into Sebakwe River, Zimbabwe, is a significant human health risk from $\mathrm{Pb}$ poisoning [95]. However, in the Nyl River floodplain Ramsar site, Greenfield et al. [96] 
attributed the low ug $\mathrm{L}^{-1}$ heavy-metal concentrations ( $\mathrm{Zn}, \mathrm{As}, \mathrm{Cu}, \mathrm{Cd}, \mathrm{Fe}, \mathrm{Se}, \mathrm{Pb}, \mathrm{Al}$, $\mathrm{Cr}$, and $\mathrm{Mn}$ ) in the $\mathrm{Nyl}$ River to geogenic origins with values below the South African maximum allowable limits for water quality [89].

\section{Orange-Senqu Basin}

At about $900,000 \mathrm{~km}^{2}$ and the second-largest, the Orange-Senqu Basin covers nearly half of South Africa in the central region, entire Lesotho (Senqu Basin), Southern Botswana, and parts of Southern Namibia [97]. A basin-wide study by UNDP-GEF [98] on humanmediated heavy-metal and risk assessments noted high-risk areas (and risk elements), including Molo Eye (Cr, Mn, Ga, Ni, Ag, and Se); Vaal (U); Riet and Koranna Spruit; Caledon and Makbomatso (several elements); Skoon Spruit (Fe and Ni); and Fish River (As). The elemental bioavailability to aquatic biota was in the order $\mathrm{Rh}<\mathrm{Ag}<\mathrm{Sn}<\mathrm{Au}$ $<\mathrm{Rb}<\mathrm{Pt}$. Additionally, As and Be were detected in fish tissue and bird eggs during the study. Recent findings in the Vaal Basin by Moloi et al. [99] from two Maluti-a-Phofung Municipality rivers, Eland and Wilge, and Iloms et al. [54] from Vaal River indicated increased noncarcinogenic human health risks from the consumption of water containing elevated levels of $\mathrm{As}, \mathrm{Cu}, \mathrm{Pb}$, and $\mathrm{Zn}$. A similar study on the Sand River, Limpopo Province noted the increased risk to the Pb levels from consuming the river's fish [100]. In KwaZuluNatal, agroindustrial pollution is a significant source of $\mathrm{Cr}$, contamination, mobility, and enrichment in the Palmiet and Sezela Rivers [101].

In Lesotho, mining at Letseng Diamonds mines has negatively impacted the ecosystems of Mokhotlong District via soil erosion, site contamination, surface water pollution from mining waste, land degradation from nonbiodegradable litter, and the accumulation of toxic waste landfills [102]. Separately, a major tributary to Orange River, Lesotho's Caledon (Mohokare) River, a key water supply source to Lesotho and South Africa (Lesotho Highlands Water Project), received above allowable $\mathrm{mg} \mathrm{L}^{-1}$ limits for Fe (0.5) and Mn (0.7) in untreated effluents from textile industries around Maseru, raising concerns about the rising aquatic pollution $[53,103]$. 
Table 1. Basin characteristics, environmental threats, and selected studies on heavy-metal mining impacts to lotic systems of Southern Africa.

\begin{tabular}{|c|c|c|c|c|c|}
\hline No & Basin & Countries & Basin Overview $[3,49]$ & Environmental Threats $[3,49]$ & $\begin{array}{c}\text { HM Pollution Threats and } \\
\text { Selected Studies }\end{array}$ \\
\hline 1 & Zambezi & $\begin{array}{l}\text { Angola, Botswana, Malawi, } \\
\text { Mozambique, Namibia, Tanzania, } \\
\text { Zambia and Zimbabwe }\end{array}$ & $\begin{array}{l}\text { Basin area: } 1.4 \text { million } \mathrm{km}^{2}(17.3 \% \text { of SA). } \\
\text { Zambezi river length: } 2574 \mathrm{~km} . \\
\text { Important tributaries: Luena and } \\
\text { Lungue-Bungo (Angola); Chobe (Botswana); } \\
\text { Shire (Malawi); Luiana (Namibia); Kabompo, } \\
\text { Kafue and Luangwa (Zambia). } \\
\text { Basin population > } 30 \text { million. }\end{array}$ & $\begin{array}{c}\text { Climate change impacts; mineral } \\
\text { mining and agricultural pollution; } \\
\text { competing uses: agroindustrial and } \\
\text { hydropower. }\end{array}$ & $\begin{array}{l}\text { Sediment-water-biota } \\
{[12,58-60,62,104]}\end{array}$ \\
\hline 2 & Pungwe & Mozambique and Zimbabwe & $\begin{array}{l}\text { Basin area: } 31,150 \mathrm{~km}^{2}(0.45 \% \text { of SA). } \\
\text { Main tributaries located in Zimbabwe: Honde, } \\
\text { Nyazengu, Chiteme, Nyamhingura, Nyawamba, } \\
\text { Nyamukombe and Rwera. } \\
\text { Population > } 1.6 \text { million }\end{array}$ & $\begin{array}{l}\text { Climate change and land degradation } \\
\text { impacts; water pollution from alluvial } \\
\text { gold mining. }\end{array}$ & $\begin{array}{c}\text { Sediment-water-biota } \\
{[74,75,78,80]}\end{array}$ \\
\hline 3 & Buzi & Mozambique and Zimbabwe & $\begin{array}{l}\text { Basin area: } 31,000 \mathrm{~km}^{2}(0.45 \% \text { of SA). } \\
\text { Buzi river length: } 250 \mathrm{~km} . \\
\text { Main tributaries: Revue and Lucite. } \\
\text { Basin population > } 1.2 \text { million. }\end{array}$ & $\begin{array}{l}\text { Floods and drought events; pollution: } \\
\text { agrochemicals, industries; } \\
\text { deforestation; riparian degradation; } \\
\text { unregulated alluvial gold and } \\
\text { diamond mining and sedimentation; } \\
\text { hydropower dam development; } \\
\text { irrigation water overdraw. }\end{array}$ & $\begin{array}{c}\text { Sediment-water-biota } \\
{[77,78,80,81,84]}\end{array}$ \\
\hline 4 & Save & Mozambique and Zimbabwe & $\begin{array}{c}\text { Basin area: } 110,420 \mathrm{~km}^{2}(1.4 \% \text { of SA }) \\
\text { Save river length: } 740 \mathrm{~km} . \\
\text { Main tributary: Runde. } \\
\text { Basin population }>3.3 \text { million }\end{array}$ & $\begin{array}{l}\text { Climate change; ecosystem } \\
\text { degradation; pollution: agroindustrial; } \\
\text { mineral mining; hydrological flows: ca. } \\
\quad 60 \text { dams constructed. }\end{array}$ & $\begin{array}{c}\text { Sediment-water-biota } \\
{[82-85]}\end{array}$ \\
\hline
\end{tabular}


Table 1. Cont.

\begin{tabular}{|c|c|c|c|c|c|}
\hline No & Basin & Countries & Basin Overview $[3,49]$ & Environmental Threats $[3,49]$ & $\begin{array}{c}\text { HM Pollution Threats and } \\
\text { Selected Studies }\end{array}$ \\
\hline 5 & Limpopo & $\begin{array}{c}\text { Botswana, Mozambique, South } \\
\text { Africa, Zimbabwe }\end{array}$ & $\begin{array}{c}\text { Basin area: } 408,000 \mathrm{~km}^{2} \text { (5.0\% of SA). } \\
\text { Limpopo river length: } 1750 \mathrm{~km} . \\
\text { Important tributaries: Olifants/Elephant, } \\
\text { Crocodile, Luvuvhu, Marico, Mzingwane, } \\
\text { Mwenezi and Shashe. } \\
\text { Basin population > } 17 \text { million. }\end{array}$ & $\begin{array}{l}\text { Climate change; agro-industrial and } \\
\text { municipal pollution; mining } \\
\text { expansion; water scarcity from } \\
\text { irrigated agriculture. }\end{array}$ & $\begin{array}{l}\text { Sediment-water-biota } \\
{[46,86-88,91,92,96,105]}\end{array}$ \\
\hline 6 & Orange-senqu & $\begin{array}{l}\text { Botswana, Lesotho, Namibia, } \\
\text { South Africa }\end{array}$ & $\begin{array}{c}\text { Basin area: } 900,000 \mathrm{~km}^{2}(11.1 \% \text { of SA). } \\
\text { Orange river length: } 2300 \mathrm{~km} \text {. } \\
\text { Important tributaries: Senqu and Caledon } \\
\text { (Lesotho); Vaal (South Africa); Fish River } \\
\text { (Namibia). } \\
\text { Basin population > } 20 \text { million. }\end{array}$ & $\begin{array}{l}\text { Climate change/variability; land } \\
\text { degradation; increasing water demand; } \\
\text { declining water quality: agroindustrial } \\
\text { pollution, domestic and heavy mining; } \\
\text { changes in hydrology; damming; } \\
\text { population growth/settlements. }\end{array}$ & $\begin{array}{l}\text { Sediment-water-biota } \\
{[52-54,98,99,101]}\end{array}$ \\
\hline
\end{tabular}




\subsection{Threats to Southern African Lotic System Biodiversity from Metal Mining and Processing}

Despite containing a dismal $0.01 \%$ of Earth's water, freshwater ecosystems support over $6 \%$ and above $10 \%$ of the global biodiversity and known species, respectively $[22,106]$. However, the increased global demand for freshwater resources threatens these ecosystems and their inherent biodiversity [107]. Such threats include water pollution, habitat destruction and degradation, resource overexploitation, streamflow modification, and species invasions or introductions [106]. Africa's freshwater biodiversity is more than ever under threat from multiple anthropic factors exacerbated by climate change impacts, leading to species and habitat loss [108]. In the mining rivers basins of SA, the most important anthropogenic threats include water pollution (e.g., acid mine drainage and metal ions/metalloids); habitat degradation/destruction (e.g., open-cast, ground, and alluvial mining); and flow modification (abstraction, diversion, and effluent discharges). The magnitude of these threats depends on the source, type, nature, and quantity of mininggenerated contaminants entering the aquatic systems. For instance, both hydraulic and hard rock mining accelerates the release of toxic metals (e.g., $\mathrm{Pb}, \mathrm{Zn}$, and $\mathrm{Hg}$ ); metalloids (e.g., As and $\mathrm{CN}$ ); and other substances (e.g., acids) via runoff or leaching (Figure 2), causing physical and chemical disturbances to stream ecosystems and exacerbating the biodiversity loss [109]. Additionally, minerals like diamonds and gold, frequently mined in water-scarce environments, demand the abstraction of significant volumes of water for extraction [110], exposing aquatic ecosystems to increased water stress and shrinking habitats, already exacerbated by episodic stream drought and climate change events [111-113].

\subsubsection{Source-Receptor Pathways of Metal Mining Pollutants in Aquatic Systems}

In mining-dominated river basins, stream water and sediment pollution result from the surface and subsurface runoff/leaching of excessively heavy-metal-laden solid and liquid wastes, mostly anthropogenic (Figure 3). Acid mine drainage (AMD) is of environmental concern to aquatic systems in such regions. Besides transporting elevated concentrations of heavy metals and metalloids, AMD alters the streamwater chemistry by increasing the acidity to $\mathrm{pH}<4[114,115]$. At low water $\mathrm{pH} / \mathrm{Eh}$ in an anoxic environment, the bioavailability and toxicity of $\mathrm{HM}$ (e.g., $\mathrm{Pb}$ and $\mathrm{Zn}$ ) in AMD is enhanced, more so by the presence of organic matter, carbonate minerals (e.g., hydrocerussite), and iron(III) hydroxides and oxides [116]. Ettler et al. [63] observed an increase in the percentage of orally bioaccessible $\mathrm{Pb}$ (24-95), V (21-100), and $\mathrm{Zn}(54-81)$ at $\mathrm{pH}<1.5$ in slag-dust-contaminated air at the Kabwe mining town of Zambia, indicating a potential environmental and human health risk. In the Kombat, Berg Aukas, and Tsumeb polymetallic mining areas of Northern Namibia, the exceptionally high oral bioaccessibility of $\mathrm{Pb}$ and As in mining dust was triggered under highly soluble phases and acidic gastric conditions [117].

In the aquatic environment, the low $\mathrm{pH}$ of water similarly lowers the diversity of communities of aquatic biota, including microbes [118], periphyton, macroinvertebrates, and fish, by increasing the bioavailability and toxicity of HM [119-121]. Additionally, the ecotoxicity of streamwater to aquatic biota increases with elevated levels of ionic and complexes of heavy metals, which can bioaccumulate and bioaugment in the aquatic ecosystem [122,123]. Aquatic microbiota; benthos; and larger organisms (e.g., fish, amphibians, and reptiles) tend to bioaccumulate and subsequently biomagnify heavy metals and increase their toxicity to other secondary consumers, including terrestrial wildlife and humans [104,124-126]. Further, the thermodynamic solubility characteristics and local chemistry of contaminant-containing mineral waste effluents in the aquatic media influence their mode of transport, chemical reactivity, and toxicity to aquatic biota $[127,128]$. 


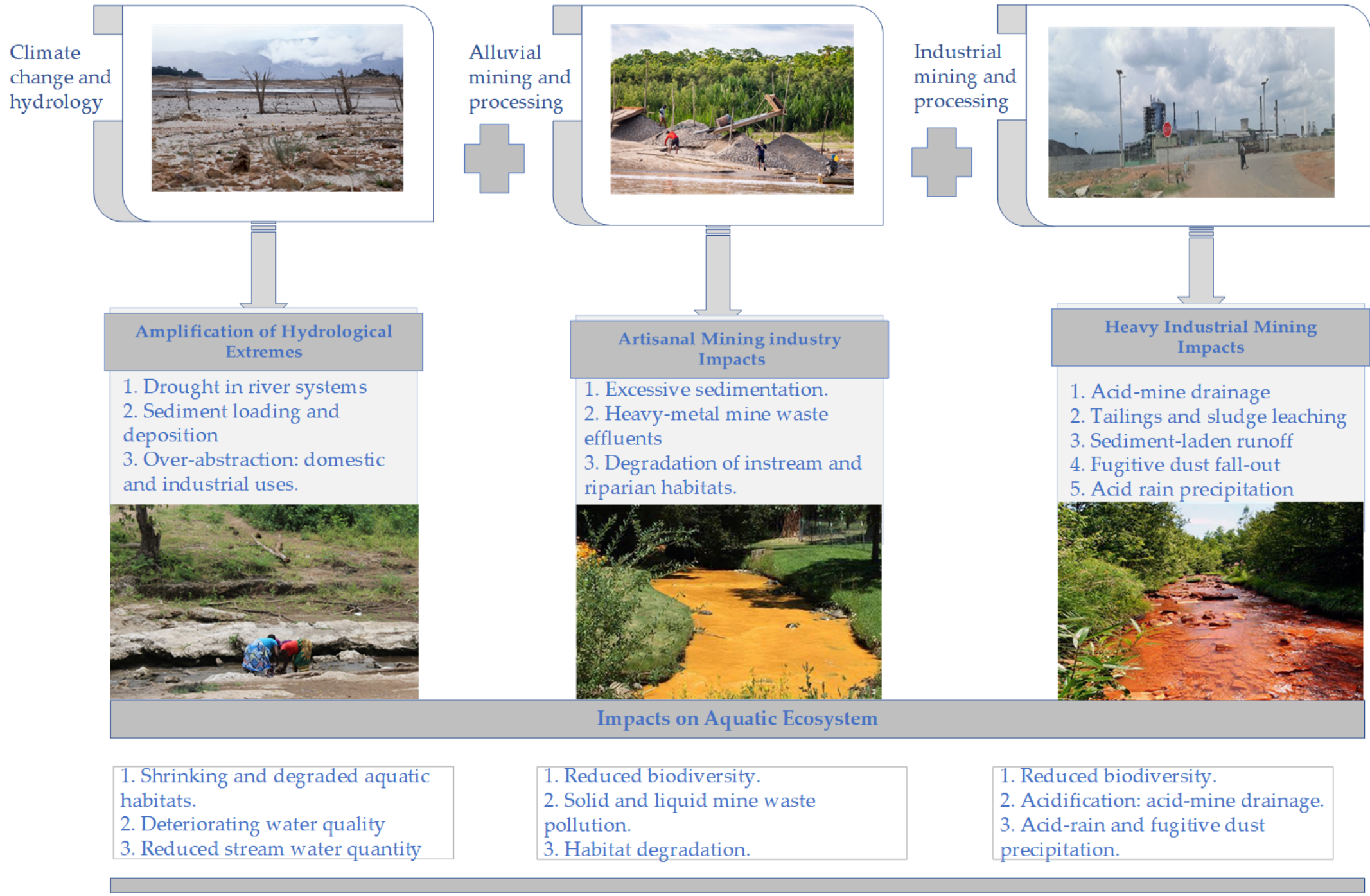

Figure 2. Threats to aquatic biodiversity and stream ecosystem functions from artisanal and industrial mining in river basins. The impacts of mining are further accentuated by the negative influences of climate change on stream hydroecology. Photo credits and copyrights: A. Hendricks; J. Houston; X. Rana; K. O. Ouma; L. Iaccino. 
Depending on the water chemistry, stream sediments can act as sinks and sources of heavy metals in polluted rivers (Figure 3). This dual role depends on the dissolution and precipitation processes of the discrete heavy-metal phases, as determined by the ambient stream water chemistry and thermodynamic properties [129]. In Pb-contaminated sediments, "the mineral forms (e.g., $\mathrm{PbSO}_{4}, \mathrm{PbCO}_{3}$ ), and $\mathrm{Pb}^{2+}$ adsorbed to $\mathrm{Fe}$ and $\mathrm{Mn}$ (hydr)oxides are comparatively inert" [128]. However, the carbonates, oxides, and sulphates of $\mathrm{Pb}$ readily dissolve under a highly acidic environment, posing significant environmental risks [130]. An increased accumulation of sediment-associated heavy-metal nanoparticles (HM-NPs) subsequently increases the ecotoxicity risk due to bioaccumulation in stream benthic communities. For example, oxidative hepatopancreatic and gonadal damage has been observed in the gastropod Bellamya aeruginosa after exposure to $\mathrm{Cu}$ (180- $\mu \mathrm{g} \mathrm{g}^{-1}$ dry weight (DW)) as CuO-NPs over 14 days [131]. The sediment toxicity to aquatic biota can also be monitored using genetic and metabolic changes among various species of the benthic communities, e.g., chironomids and gastropods [132].

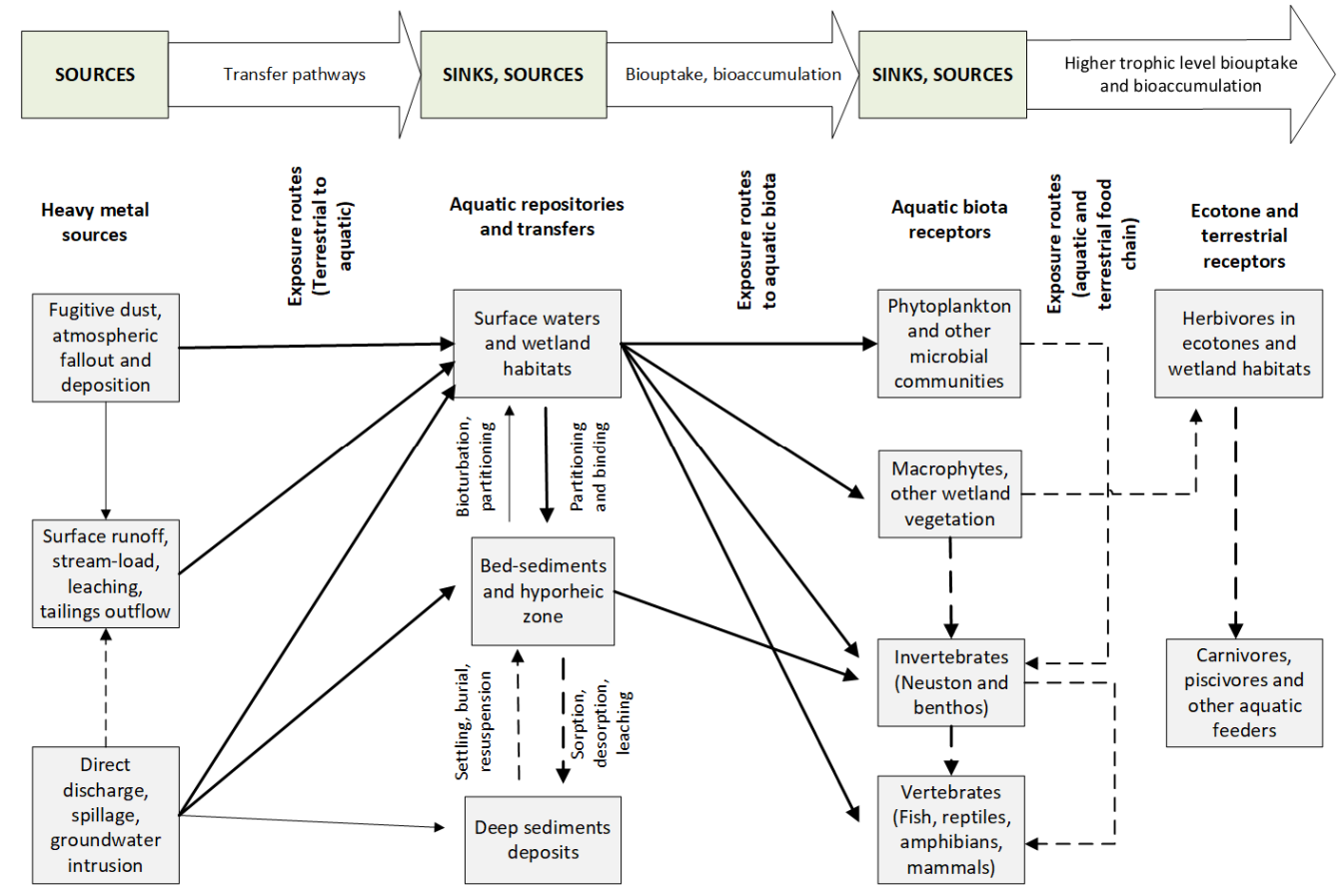

Figure 3. Conceptualised exposure pathways of aquatic biota to heavy metal pollution in surface and ground waters draining mining landscapes. The arrow density directly correlates to the importance of the respective exposure pathway. Based on the interplay between biotic and environmental components, the model is developed from the contaminant exposure concept in Giddings et al. [133].

Figure 3 illustrates the pathways through which heavy-metal contaminants enter the aquatic ecosystem from multiple sources. Runoff, leaching, erosion, and wastes from tailings dams are highly significant metal contaminant sources. Atmospheric gases and other HM waste-laden fugitive dust are also significant pollution contributors. Exposure to heavy-metal contaminants in an aquatic environment can occur at different interphases: from allochthonous sources (e.g., surface runoff, spills, direct application, and groundwater intrusion); within the various aquatic repositories (e.g., water and sediment); biouptake by aquatic receptors (e.g., microbiota, invertebrates, macrophytes, and vertebrates); and export into the terrestrial food chain by wildlife and other tertiary consumers (e.g., humans). Surface waters and wetlands contribute significantly to biologically available heavy-metal contaminants to biota within aquatic systems. In contrast, surface and deep sediments serve as temporary sinks (e.g., adsorption and burial) or sources (e.g., desorption, biotur- 
bation, and resuspension), as determined by the water chemistry, thermodynamic, and hydrological processes [129].

\subsubsection{Toxicity of Selected Heavy-Metal Pollutants to Macroinvertebrate} and Macrophyte Communities

The elevated presence of heavy metals beyond geogenic concentrations in aquatic systems is traceable to human-mediated agroindustrial pollution. Heavy metals biocentrate and bioaccumulate in aquatic biota and persist in the water-sediment matrix [134]. High and toxic levels of $\mathrm{As}, \mathrm{Cr}, \mathrm{Hg}, \mathrm{Pb}, \mathrm{Cu}, \mathrm{Ni}$, and $\mathrm{Zn}$ are frequently reported in aquatic environments [135]. Some elements, such as $\mathrm{Ni}, \mathrm{Cu}, \mathrm{Cr}$, and $\mathrm{Zn}$, are essential metabolic components at trace concentrations but cause systemic toxicity above permissible thresholds $[61,136]$. Other elements (e.g., $\mathrm{Pb}, \mathrm{Hg}$, and $\mathrm{As}$ ) are toxic to aquatic organisms, even at trace levels [137].

\section{Arsenic (As)}

Due to the high bonding affinity with other natural elements, As naturally occurs as a major ingredient in over 200 mineral ores, mainly as elemental As, arsenide, arsenate, phosphate, sulphide, arsenite, and oxide mineral forms released biogeochemically during oxidation, reactive desorption, or chemical and bioleaching processes $[137,138]$. As is also introduced anthropogenically via agrochemical processing byproducts and mining effluent discharges into natural water systems $[139,140]$. The inorganic As forms are considered more toxic than the organic derivatives, with marked differences in their biochemical effects on aquatic biota [141].

In the aquatic matrix, the As toxicity varies with the water chemistry (e.g., $\mathrm{pH}$ and redox potential), presence of oxides (e.g., Fe and Mn) [142], and microbial activities (e.g., algal biosorption) [137]. As exists mainly in four oxidation and $\mathrm{pH}$-dependent states as arsenite (As(III)), arsenate $(\mathrm{As}(\mathrm{V}))$, and arsenic $(\mathrm{As}(0))$ and arsine (As(-III)) [143]. As(III) and $\mathrm{As}(\mathrm{V}))$ are the most abundant inorganic forms, where the transformations between the two are $\mathrm{pH}$ - and Eh-dependent. Microbial biochemical processes in water convert the dominant inorganic As species to methylarsenicals and high-order organoarsenic forms such as arsenosugars, which bioaccumulate in living tissues [144]. Under anoxic conditions, anaerobic bacteria reduce biomethylated inorganic As to the organic monomethlyarsonic (MMA) and dimethlylarsinic (DMA) acid metabolites that are more mobile in water [145,146]. In the agricultural sector, the two organic compounds MMA and DMA, the active ingredients of organic herbicides, enter the aquatic environment via point or diffuse sources [146].

As (III) is more soluble and, hence, more readily bioavailable and toxic than $\mathrm{As}(\mathrm{V})$ to aquatic organisms under reducing Eh conditions and low $\mathrm{pH}$, particularly the metallophytic hyperaccumulator macrophytes (e.g., Water hyacinth, duckweeds, water ferns, water cabbages, and watercress) [140]. Falinski et al. [147] recorded As bioaccumulation up to 0.572 and $0.075 \mathrm{mg} \mathrm{L}^{-1}$, respectively, for two edible macrophytes, Nasturtium officinale (watercress) and Diplazium esculetum (vegetable fern), of Hawaii. The corresponding potential human health risk quotients were 0.12 and 0.03 . In the coontail (Ceratophyllum demersum L.), tissue accumulation of $0.302-\mathrm{mg} \mathrm{As}^{-1}$ DW exhibited necrosis and biomass reduction over 48-h exposure to As(III) [142].

As toxicity on macroinvertebrate communities results in lower biodiversity, reduced population densities, changes in population structure, and ultimately, lower community biomass. Canivet et al. [148] and Chi et al. [149] observed a significant absence of sensitive EPT (Ephemeroptera, Plecoptera, Trichoptera) taxa (e.g., Heptagenia sulphurea and Hydropsiche pellucidula), the abundance of more tolerant Chironomidae (e.g., Cardiocladius sp.), and transition to tolerant predator functional feeding combined with the disappearance of filter feeders, scrappers, and collectors from As toxicity in an aquatic environment.

\section{Chromium (Cr)}

Chromium occurs naturally in the nontoxic trivalent $\left(\mathrm{Cr}^{3+}\right)$ state. However, $\mathrm{Cr}^{3+}$ oxidises to the toxic hexavalent $\left(\mathrm{Cr}^{6+}\right)$ form on exposure to water and air. $\mathrm{Cr}^{3+}$ is soluble 
over a wide $\mathrm{pH}$ range $[150,151]$. Prolonged exposure of freshwater crustacean amphipods (e.g., Gammarus and Niphargus sp.) and isopods (e.g., Asellus sp.) to a half-maximal lethal concentration $\left(\mathrm{LC}_{50}\right)$ of $\mathrm{Cr}^{6+}$ exhibited toxic sensitivity [148]. However, the trait-based evaluation of physiological sensitivity to $\mathrm{Cr}$ and other heavy metals ranked crustaceans (molluscs and bivalves) above cladoceran and trichopteran insect orders [152]. Cr pollution has caused a longitudinal decline in macroinvertebrate taxa richness in river systems [94]. For instance, in Hex River draining the Bushveld Igneous Complex platinum mining region of South Africa, the $\mathrm{Cr}$ body loads for macroinvertebrate taxa increased downstream. The benthic Tubificidae accumulated the highest $\mathrm{Cr}\left(92 \mu \mathrm{g} \mathrm{g}^{-1}\right)$, followed by Libellulidae

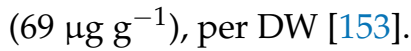

In macrophytes (e.g., Pistia stratiotes and Salvinia herzogii), Cr bioaccumulation occurs via ion exchange, adsorption, and chelation processes [154]. Toxicity from $\mathrm{Cr}$ in macrophytes manifests as changes in the chloroplast ultrastructure and cell malignancy. Cell death, tissue necrosis, and root wilting may also result from Cr poisoning $[150,154]$. Different macrophyte species display varying tolerance levels to $\mathrm{Cr}$ toxicity. For instance, in China's Taihu Basin aquatic systems with a mean $92.4 \mathrm{mg} \mathrm{kg}^{-1}$ of sediment and $5.4 \mathrm{ug} \mathrm{L}^{-1}$ of $\mathrm{Cr}$ concentrations, Potamogeton malaianus, Nymphoides peltata, Eichhornia crassipes, and Hydrilla verticillata, $\mathrm{Cr}^{6+}$ phytouptake ranged between 4.2-44.2, 1.5-8.4, 1.7-5.5, and 3.410.4-mg kg ${ }^{-1}$ DW, respectively, against the $5-30-\mathrm{mg} \mathrm{kg}^{-1}$ DW toxic level criteria [155]. Macrophytes have been used extensively in the phytoremediation of $\mathrm{Cr}^{6+}$ toxicity, e.g., Pistia stratiotes is a better hyper-accumulator for $\mathrm{Cr}$ in an aqueous $\mathrm{Co}-\mathrm{Cr}$ environment, hence significantly reducing the $\mathrm{Cr}$ toxicity over two-fold compared to Co removal [156].

\section{Copper $(\mathrm{Cu})$}

Jeppe et al. [132] examined sediment-derived Cu toxicity to stream macroinvertebrates at the subindividual and population levels. The authors noted genetic and metabolomic changes in Chironomus tepperi (Chironomidae) at $\mathrm{EC}_{50}$ and $60-\mathrm{mg} \mathrm{kg}^{-1} \mathrm{Cu}$. However, this taxon was most tolerant to $\mathrm{Cu}$ toxicity at $\mathrm{EC}_{50}$ with up to $94.5 \%$ survival. A rapid decline in the highly sensitive mayfly (Rithrogena sp.) population coupled with $\mathrm{Cu}$ bioaccumulation in caddisfly (e.g., Brachycentrus sp.) tissues indicates the heavy-metal toxicity of aquatic insect communities [157,158]. Additionally, Joachim et al. [159] observed a reduced abundance, richness, and diversity of macroinvertebrates, emergent insects, and zooplankton on prolonged exposure to $25-75$-ug L ${ }^{-1} \mathrm{Cu}$ concentrations.

Macrophytes are suitable for biomonitoring and phytoremediation due to their ability to bioaccumulate and bioconcentrate heavy metals in aquatic environments. Lemna minor, Elodea canadensis, and a moss (Leptodictyum riparium) have excellent biouptake and removal capabilities for $\mathrm{Cu}, \mathrm{Cd}, \mathrm{Pb}$, and $\mathrm{Zn}$ [160]. E. canadensis has been used to monitor $\mathrm{Cu}$ toxicity [161]. However, sublethal heavy-metal doses alter the chloroplast ultrastructure, cause cell plasmolysis, and eventually reduce the biomass [160,161]. There is evidence of $\mathrm{Cu}$ build-up inducing oxidative stress by limiting the antioxidant enzymatic activity and chlorophyll content in free-floating coontail (Ceratophyllum demersum L.) and duckweed (Spirodela polyrhiza) [162,163].

\section{Mercury (Hg)}

Methylmercury ( $\mathrm{MeHg}$ ) is considered the most bioavailable and toxic form in aquatic environments [164]. This organomercury forms rapidly in aquafauna since $\mathrm{MeHg}$ is lipophilic, passes through cells, and has a high affinity for amino acids [165]. MeHg toxicity in the aquatic food web is amplified in the organic form through bioaccumulation and biomagnification. For instance, the shoots of Elodea nuttallii can accumulate up to $60 \% \mathrm{MeHg}$ intracellularly from water and sediments, hence availing it to higher trophic levels [166]. Mercury toxicity is an environmental cause of systemic imbalance in aquafauna, e.g., oxidative stress and neurotoxicity [167].

MeHg uptake by stream macroinvertebrates can be used to predict bioaccumulation and the lateral-vertical transfer of $\mathrm{Hg}$ in the aquatic food web $[168,169]$. Macroinvertebrate 
functional feeding groups (e.g., obligate predators) can also be used as surrogates to monitor $\mathrm{Hg}$ pollution in heavy-metal-polluted streams [170]. Mercury methylation in macroinvertebrates mainly occurs from stream sediment repositories [164].

Zinc (Zn)

Most $\mathrm{Zn}$ in freshwater systems increasingly adsorbs into sediments and humic substances at high temperatures, low oxygen levels, and low $\mathrm{pH}$. In dissolution, hexa-aqua zinc $\left(\mathrm{Zn}\left(\mathrm{H}_{2} \mathrm{O}\right)^{2+}{ }_{6}\right)$ is the most stable and highly toxic to aquatic biota [171]. Most aquatic organisms can tolerate bioavailable $\mathrm{Zn}$ concentrations below $100 \mu \mathrm{gL}^{-1}$ [172]. However, at elevated levels, $\mathrm{Zn}$ toxicosis lowers the metamorphosis and emergence rate of adult stages of freshwater insect communities [173]. The presence and toxicity of $\mathrm{Zn}$ in ternary mixtures of heavy metals in streams lowers the abundance of pollution-sensitive mayflies (Ephemeroptera) in aquatic species-sensitivity distribution (SSD) profiles [158].

\section{Monitoring and Assessment of Aquatic Heavy-Metal Pollution in SA River Basins}

A multidisciplinary approach to analysing aquatic ecosystems in river basins is more impactful in monitoring and assessing ecosystem integrity. Monitoring involves sampling and analysis to determine the ecological status, while assessment interprets the data to establish the system's ecological integrity [174]. This multidisciplinary consideration provides an ecological platform for a holistic study and a better understanding of "catchment ecology" under the five main ecological components [175]:

1. System conditions, which incorporate climate-related structures, characteristics, and processes.

2. System hydrology, the catchment hydrological and hydraulic processes, including lateral and longitudinal instream and terrestrial flows. Surface and groundwater interactions are also considered.

3. Structures, the morphological features that influence catchment hydrology, energy and material transfers, and retention/recycling potentials.

4. Substances, the longitudinal qualitative and quantitative determination of dissolved components, such as pollutants, gases, ions, and nutrients as load transport in lotic ecosystems.

5. Biotic, the response of living components to the functioning of the above controlling abiotic factors. This component includes the taxonomic and ecosystem responses and biotic processes, like primary production, respiration, competition, reproduction, and trophic relationships. Biotic responses to the controlling factors are an essential indicator for catchment management and biodiversity conservation.

Building on the five components, a TRIAD assessment of the ecological integrity of catchment ecosystems, which integrates the biological, ecotoxicological, and physicochemical data, has been proposed $[176,177]$.

\subsection{Physicochemical Monitoring and Assessment}

In most environmental assessment initiatives, physical and chemical surveys frequently take precedence to determine the pathways for further investigations, including biological method integration. Physicochemical monitoring provides feedback mechanisms since fluctuations in the water quality can be rapidly detected and further reference-based monitoring action taken when or where necessary. Any aquatic system's physical and chemical attributes significantly influence its biotic structure and functions [178].

SA river systems' physical and chemical water qualities have been extensively documented and used to categorise their ecological statuses $[43,62,179]$. Heavy-metal pollution in the different aquatic matrices of SA lotic systems has received increasing attention over the past decades due to the associated negative ecological impacts [96,180-183]. The pollution intensity and environmental impact of HM contamination will likely increase with the demand for raw materials, advances in industrial mining and processing technologies, and expansion of areal mining in the SA region. 


\subsection{Bioindicators, Biomonitoring, and Bioassessment}

Biological monitoring (biomonitoring) initiatives have gained popularity in SA due to their cost-effectiveness, eco-friendliness, rapid application, and integration into aquatic assessment programmes [26]. While physical and chemical monitoring can be used to reveal the direct and instantaneous effects of HM pollutants in the aquatic matrices, biotic communities offer the advantage of revealing the integrated and "historic" impacts of pollutants on both the biota and the ecosystem. Biomonitoring uses bioindicators such as free-floating algae, the periphyton complex, macrophytes, invertebrates (zooplankton, insects, molluscs, and gastropods); and vertebrates (fish, amphibians, reptiles, and large mammals) to evaluate contaminations in the environment. Zhou et al. [184] defined biomonitoring as a "scientific technique for assessing the environmental and biotic exposures to pollutants, based on sampling and analysis of the target matrix". Biomonitoring uses markers (biological or chemical signatures) to reflect the potential impact or ecotoxicity of anthropogenically produced pollutants on the bioindicators and the environment.

Suitable bioindicators are based on several desirable biological and physical attributes. However, since it is virtually impractical to find such organisms, a bioindicator with representative qualities may serve the specific objectives of biomonitoring. For instance, in using fish, the abundance, ubiquity, tolerance or sensitivity, sedentary nature, trophic status, and life history can be considered when selecting appropriate species [184]. Bioindicators can be categorised based on the objectives of bioindication as diagnostic, compliance, and early warning indicators or, according to their application, into biodiversity, environmental, and ecological indicators [185].

\subsubsection{Macroinvertebrate and Fish-Based Assessment}

The suitability of macroinvertebrates as bioindicators in lotic systems lies in their ability to reflect the magnitude of aquatic degradation spatiotemporally using well-established assessment methods and indices [50,186-190]. The sedentary macroinvertebrate communities, particularly Ephemeroptera, Plecoptera, and Trichoptera (EPT), have been widely used as bioindicators of aquatic pollution, integrating both water and habitat qualities $[87,184,191]$. Macroinvertebrates have been used to assess heavy metal contamination in Southern African riverine systems [26,92,188,192,193]. In South Africa's Bushveld platinum mining complex, metal accumulation varied in different functional feeding groups of macroinvertebrates. The epibenthic taxa (Tubificidae and Chironomidae) accumulated higher concentrations of $\mathrm{Cr}$ and $\mathrm{Pt}$ than the water column feeders, scraper grazers (Lymnaediea), shredders (Baetidae), and predators (Coenagrionidae) [153]. Phiri [94] noted a sharp decline in macroinvertebrate taxa along the lower reaches of Mukuvisi River in Harare, Zimbabwe, which was dominated by tolerant oligochaetes and chironomids due to elevated $\mathrm{Fe}, \mathrm{Cr}, \mathrm{Cu}$, and $\mathrm{Zn}$ loads in the streamwater.

Fish, due to their desirable biological attributes, such as size, habitat variability, life cycle, ease of culture and taxonomic identification, trophic level, and socioeconomic significance, qualify their relevance, preference, and wide application in the biomonitoring and bioassessment of aquatic ecological integrity [174]. Fish as bioindicators can represent aquatic degradation at local and regional scales. The behavioural (growth, reproduction, metabolism, and feeding), biochemical (biomarkers), and the sublethal response of fish to metal pollution have been suggested for biomonitoring [194]. High metal (Co, Cd, and $\mathrm{Zn}$ ) concentrations have been detected in tissues of the highly adaptive African catfish (Clarias gariepinus) and the Nile Tilapia (Oreochromis niloticus) in an HM-polluted reservoir, Eleyele Lake, in Nigeria [195]. Histopathological studies on fish have also established the relationship and the severity of heavy-metal pollution on fish health and susceptibility to diseases [196]. HM bioaccumulation in the endocrine system of fish in Kafue River, Zambia, has potentially negative effects on reproduction by depressing sex hormones [197]. Further, the sequestration of $\mathrm{HM}$ in fish tissues and organs is emerging as a human and aquatic ecological health concern [198-200]. 


\subsubsection{Microphytes, Periphyton, and Macrophytes}

All three groups respond to water quality changes by variations in the species spectrum and abundance. However, the microphytes (phytoplankton and phytobenthos) and periphyton display quicker reactions more appropriate for short-term investigations. Microphytes, other heterotrophic microbes, and organic matter complexes form a periphytic matrix attached to submerged surfaces in the aquatic environment. Due to their very short life cycles and high reproduction rates, periphyton respond quickly to environmental pollution. Besides the individual plankton communities, periphyton can also be suitable for detecting short-term and sudden environmental variations.

Additionally, the ubiquitous nature and extensive knowledge of periphyton ecology within the scientific community makes periphyton suitable for monitoring and assessing aquatic HM pollution $[18,184,201-203]$. Benthic diatoms and filamentous green algal assemblages are useful in evaluating biotic responses to mining pollutions in stream ecosystems [204-206]. Respectively, several diatom-based biotic indices have been developed to assess the ecological integrity of SA river systems, including the Trophic Diatom Index (TDI) and the South African Diatom Index (SADI) [26,204].

Several macrophyte species, including Eichhornia, Ludwigia, Polygonum, Pistia, Cyperus, Lemna, Elodea, Typha, and Azolla, have been used to study HM contamination dynamics in tropical aquatic environments $[135,160,207,208]$. Macrophytes are appropriate bioagents for the long-term monitoring of aquatic ecosystem health due to their sedentary nature, high diversity, abundance, ease of identification and handling, and tolerance to HM pollution $[105,209,210]$. Changes in the macrophyte community structure and composition can also be a valuable indicator of pollution trends and alterations of the stream water quality $[184,211]$.

\subsection{Approaches in Biomonitoring and Bioassessment of Aquatic Ecosystems}

3.3.1. Ecological Tools and Models

Ecological assessment tools employ a cocktail of physical, chemical, and biotic components to evaluate the ecosystem integrity. Oberholster et al. [205] used the Ecological Screening Tool (EST) comprising physical-chemical and biological phases. The EST used a weight-of-evidence approach to determine the impact of acid mine drainage (AMD) on the health of the Bloubane Stream in South Africa. Beyond the ecological assessment tools, ecological models are developed to explain the composition and variability of ecosystems' aquatic communities. For instance, the step-wise stress model uses indicators in the pressure-state-impact-response (PSIR) chain at ecosystem-level responses, using biodiversity and sustainability parameters [185]. Other complex models for ERA have also been developed, from food web- and ecosystem- to socioecological-based scales [212]. The ecosystem model is the most relevant in our context since it evaluates the response of biotic and abiotic components to perturbations, e.g., pollutants or ecosystem modifications. Ecosystem models are developed from the input of multivariate, multimetric, and population or community biotic response indices.

\subsubsection{Multivariate Methods}

Multivariate indices (MIs) are model-oriented predictive systems that compare the observed ecological status and referenced conditions projected from pristine environmental conditions from environmental parameters (e.g., reference condition approach). The multivariate approach requires in-depth knowledge of the ecology of the target biotic community, the ecosystem, and the evaluation criteria.

\subsubsection{Multimetric Indices (MMIs)}

The MMIs build on the multivariate approach and combine several quantifiable biological attributes (biometrics) and ecological characteristics of the ecosystem. The four common types of biometrics are abundance/composition, diversity/richness, sensitivity/tolerance, and functional diversity $[213,214]$. In an MMI, individual metrics are related 
predictably and reasonably to environmental pressures and impacts. Therefore, the method combines several metrics and different categories to generate a single assessment index, making the method more robust than single-metric approaches. However, there are some drawbacks during the development of the MMIs: (1) some information is lost, (2) redundancy of certainty, (3) vulnerability to compound errors, and (4) rigidity to method updates [215].

\subsubsection{Biotic Indices}

A biotic index is a numerical equivalent of biotic assemblage responses (sensitivity or tolerance) to anthropic disturbances [214,216]. Biotic indices assign different types of taxa to different sensitivity or tolerance levels based on numeric expressions (scores) of humaninduced disturbances. Biotic indices rely on the diversity approach that characterises an ecosystem based on abundance, richness, and evenness as descriptors of the community structure. Less disturbed communities usually exhibit high diversity (taxa richness) and evenness among species in an ecosystem. Biotic indices have been widely used for the rapid bioassessment of aquatic ecosystems in SA due to their robustness, sensitivity, costeffectiveness, ease of application, and interpretation [26,81,204,217].

SA has seen the development of biometric-based sampling protocols and rapid bioassessment schemes (RBS) [26]. The South African Scoring System, SASS-5 [189], uses stream macroinvertebrates to rapidly evaluate the aquatic ecosystem conditions [94,191,192,218]. Other national and regional RBSs have also been derived from the Chutter [219] SASS-1 model: the Zambian Invertebrate Scoring System (ZISS) [190], Botswana's Okavango Assessment System (OKAS) [220], the Namibian Scoring System (NASS) [221], and the Tanzania River Scoring Systems (TARISS) [222].

The South Africa fish assemblage integrity index (FAII) integrates multiple fish and habitat ecological attributes [223]. The FAII was developed from the Karr 1998 [224] fish index of biotic integrity (F-IBI) and later modified by Kleynhans [225] into the fish response assessment index (FRAI). The FRAI measures the responses of fish assemblages to the cumulative effect of environmental changes in lotic systems.

Flora-based stream integrity assessment indices have also been developed: the Zambian Macrophyte Trophic Ranking (ZMTR) system [226] and the Harding and Taylor [227] South African Diatom Index (SADI). The SADI has been successfully applied to assess the Wemmershoek River catchment and river basins in South Africa [228].

\subsubsection{Integrated Ecological Assessment (IEA)}

The IEA refers to the simultaneous linkage of biological, ecotoxicological, and physicalchemical data and ecosystem components during the ecological assessment to define an ecosystem's integrity $[25,176,177]$. Due to its compounded nature, the IEA provides "allrounded and detailed" risk assessment feedback as a basis for implementing holistic aquatic ecosystem management plans. One of the increasingly adopted IEA systems is the ERA framework $[14,229,230]$. Several studies have investigated the ecological risks of mining pollution to biotic communities in different environmental matrices [12,231-237] and human health $[10,24,195,238-242]$. Nevertheless, the scope of this paper is limited to the aquatic ecological risk assessment (AERA) of heavy-metal pollution as an emerging concern and threat to the sustainability of the health and functioning of surface water systems of SA.

\section{Aquatic Ecological Risk Assessment (AERA)}

Aquatic ecosystems are integral to the biosphere's survival since they provide requisite ecosystem goods and services. However, the ecological integrity of these systems is consistently under threat since the components providing benefits to nature and society are also highly vulnerable to deleterious anthropogenic impacts $[15,243]$. For instance, in mining environments, the major threats to freshwater ecosystems include heavy metals and metalloids [244,245], mine drainage [246,247], the fallout from atmospheric contam- 
ination [248], and sediment-laden waste pollution [249-251]. Hence, there is a need to develop an integrated method to monitor the health of aquatic ecosystems to ensure the sustained provision of benefits to nature and society [16]. AERA provides a comprehensive and reasonable approach to evaluating the current and potential anthropogenic impacts on aquatic resources [23,252].

A risk assessment determines the impact of a stressor(s) on the environmental (ecological risks) or human well-being (human health risks) [253]. An ecological risk assessment (ERA) evaluates the probability of present or potential risks driven by human actions and the likely environmental impacts [14,254]. Risks arise from a combination of the severity (nature and magnitude) and the probability (depending on the frequency of exposure) of effects from a proposed action(s) or stressor(s) [255]. The probabilities of risks may result from variability or uncertainty arising at the different tiers of the assessment framework. An action or stressor category may range from hydrological, geophysical, or biological to a chemical matrix, mostly anthropogenically mediated. Therefore, the ERA framework applies scientific knowledge and tools to evaluate the associated effects of stressors on receptors to generate useful information for a collaborative expert-guided risk management decision-making process to mitigate the different environmental stressors/risk factors [212]. The principal focus of an ERA is to minimise the probability of ecological risks evolving into possibilities (i.e., hazards) with deleterious effects by providing stakeholders with practical decision support and management tools [256].

The ERA principle was founded on three aspects of scientific inquiry: what events can occur, how they are likely to happen, and the endpoints from the set of events [257]. Therefore, the ERA process integrates three fundamental and logical phases: problem formulation, risk analysis, and risk characterisation [256,258]. Reporting to risk managers and other relevant stakeholders sets the stage for risk management or reevaluation, depending on the risk significance level [259]. The prevailing economic, social, technological, and political dynamics must be considered during risk management. Suter II et al. [255] prescribed the sociopolitical purposes of an ecological risk assessment: serving as a basis for technical decisions, providing legitimate redress to stakeholder concerns, and facilitating a common platform for stakeholder engagement and involvement in decision-making.

\subsection{Application of Pollution Factors/Indices in ERA of Aquatic Systems}

Environmental pollution indices are useful in establishing or estimating the ecological risks posed by contaminants naturally or anthropogenically introduced into different ecosystem matrices $[260,261]$. Numerous studies have applied contaminant pollution indices, such as the contamination factor (CF), degree of contamination (DC), geoaccumulation index $\left(\mathrm{I}_{\text {geo }}\right)$, enrichment factor $(\mathrm{EF})$, pollution load index (PLI), potential ecological risk factor $\left(\left(\mathrm{Er}^{\mathrm{i}}\right)\right.$, potential ecological risk index $(\mathrm{PERI})$, and the combined pollution index (PLI), for ERA and monitoring of the impacts of anthropogenic activities to the levels of HM in the environment [101,200,238,262-267].

Table 2 describes the commonly used pollution indices and their applications, strengths, and weaknesses in ERA programs. Virtually all the indices described have wide applications and provide the criteria for classifying risk levels. From Table 2, however, it is apparent that a significant proportion of these factors/indices only consider the abiotic environmental matrix as a surrogate for evaluating the current and future ecological risks. This biasedness frequently results in lopsided conclusions and recommended remedial actions concerning risks to biotic communities [268,269].

To address this challenge, Grapentine et al. [270] proposed four lines of evidence (LOE) (i.e., surface sediment chemistry, laboratory toxicity bioassays, benthic community structure, and benthic bioaccumulation and biomagnification gradients). The LOE incorporates exposure, effect, weight of evidence (WOE), and risk elements in the ERA process. Therefore, the LOE selected depends on the environmental stressors of potential concern (SOPCs) and the biological receptors of potential concern (ROPCs), based on the spatiotemporal considerations and ecological relevance. Chapman and Hollert [271] recommended 
that the application of a sedimentological analysis in ERA should ensure that the LOE applied adequately accounts for critical ERA components (Problem Formulation, Exposure, and Impacts); addresses cause-and-effect; and sufficiently considers other "nonchemical" stressors [14,255]. 
Table 2. Characteristics and applications of environmental pollution factors and indices in the ERA of heavy-metal pollution.

\begin{tabular}{|c|c|c|c|c|c|}
\hline & Index/Factor & Description and Classification & Application & $\begin{array}{l}\text { Strengths (S) and Deficiencies (D) } \\
\text { [260] }\end{array}$ & References \\
\hline 1 & Contamination Factor (CF) & $\begin{array}{c}\text { Evaluates the ratio of contamination to that of } \\
\text { background environmental HM levels. } \\
\mathrm{CF}=\frac{C_{m}}{C_{b}} \text {, where } c_{m} \text { is the concentration of } \\
\text { metal } \mathrm{m} \text {; } c_{b} \text { is the pre-industrial concentration } \\
\text { of metal m. } \\
\text { Classification: } C F<1 \text {, low contamination; } 1 \leq \\
\mathrm{CF} \leq 3 \text {, moderate contamination; } 3<\mathrm{CF} \leq 6, \\
\text { considerable contamination; } \mathrm{CF} \geq 6 \text {, very high } \\
\text { contamination }\end{array}$ & $\begin{array}{l}\text { Reflects preliminary } \\
\text { contaminant enrichment in } \\
\text { the environment. }\end{array}$ & $\begin{array}{l}\text { S: Simple and direct; individual factor } \\
\text { determined per metal; compares } \\
\text { between sample and reference } \\
\text { concentrations; precise classification } \\
\text { scale. } \\
\text { D: No account for variability from } \\
\text { natural processes; excludes the } \\
\text { potential availability of other HM; } \\
\text { requires the incorporation of } \\
\text { background reference values. }\end{array}$ & {$[232,251,261,263,272-275]$} \\
\hline 2 & $\begin{array}{l}\text { Degree of Contamination } \\
\text { (DC) }\end{array}$ & $\begin{array}{l}\mathrm{DF} \text { is the sum of all } \mathrm{HM} \text { contamination factors } \\
\text { in a particular location. } \\
\qquad \mathrm{DC}=\sum_{i=1}^{n} C F \\
\text { Classification: } \mathrm{DC}<6, \text { low degree; } 6 \leq \mathrm{DC}< \\
\text { 12, moderate; } 12 \leq \mathrm{DC}<24 \text {, considerable } \\
\text { degree; } \mathrm{DC} \geq 24 \text {, very high degree }\end{array}$ & $\begin{array}{c}\text { Estimates extent of } \\
\text { contamination from derived } \\
\text { contamination factors. }\end{array}$ & $\begin{array}{l}\text { S: Analysing unlimited HM possible; } \\
\text { evaluates a sum of CF; classification } \\
\text { scale available. } \\
\text { D: Not widely used; no account for } \\
\text { natural geochemical processes; } \\
\text { inclusion of background HM reference } \\
\text { values mandatory. }\end{array}$ & {$[12,239,250,260,261,263,276-278]$} \\
\hline 3 & $\begin{array}{l}\text { Geo-accumulation index } \\
\left(\mathrm{I}_{\text {geo }}\right)\end{array}$ & $\begin{array}{l}\text { Useful in evaluating } \mathrm{HM} \text { contamination based } \\
\text { on the ratio of the concentration in the } \\
\text { soil/ water to the geogenic background levels. } \\
\mathrm{I}_{\text {geo }}=\log _{2}\left(\frac{C_{n}}{1.5 B_{n}}\right) \text {, where } \mathrm{C}_{\mathrm{n}} \text { is the measured } \\
\text { concentration of the HM; } \mathrm{B}_{\mathrm{n}} \text { is the } \\
\text { environmental background value of the metal; } \\
1.5 \text { is the background matrix correction } \\
\text { coefficient to moderate the impact of possible } \\
\text { variations due to lithogenic and } \\
\text { anthropogenic influences. } \\
\text { Classification: } \mathrm{I}_{\text {geo }} \leq 0 \text {, uncontaminated; } 0< \\
\mathrm{I}_{\text {geo }} \leq 1 \text {, uncontaminated to moderately } \\
\text { contaminated; } 1<\leq 2 \text {, moderately } \\
\text { contaminated, } 2<\leq 3 \text {, moderately to strongly } \\
\text { contaminated; } 3<\leq 4 \text {, strongly contaminated; } \\
4<\leq 5 \text {, strongly to extremely contaminated; } \\
\text { Igeo }>5 \text {, extremely contaminated. }\end{array}$ & $\begin{array}{l}\text { Evaluates the degree of metal } \\
\text { contamination or pollution in } \\
\text { the environment. }\end{array}$ & $\begin{array}{l}\text { S: Wide usage; allows historical } \\
\text { comparison of HM contamination; } \\
\text { simplified quantitative index; } \\
\text { correction for lithogenic interferences } \\
\text { accounted for via the } 1.5 \text { correction } \\
\text { coefficient; precise classification scale } \\
\text { available. } \\
\text { W: No account for the availability of } \\
\text { HM of no interest; no account of the } \\
\text { variability of natural geochemicals. }\end{array}$ & {$[234,236,238,250,263,279,280]$} \\
\hline
\end{tabular}


Table 2. Cont.

\section{Index/Factor}

\begin{tabular}{|c|c|c|c|c|c|}
\hline & Index/Factor & Description and Classification & Application & $\begin{array}{l}\text { Strengths (S) and Deficiencies (D) } \\
\text { [260] }\end{array}$ & References \\
\hline 4 & Enrichment Factor (EF) & $\begin{array}{c}\text { Evaluates the severity / pollution state of } \\
\text { anthropogenic enrichment of individual HM. } \\
\mathrm{EF}=\frac{\left(M_{s} / C_{r e f}\right)}{\left(M_{c r} / C_{c r}\right)} \text {, where } M_{s} / C_{r e f} \text { is the ratio of } \\
\text { metal concentration in the sample to reference } \\
\text { metal } C ; M_{c r} / C_{c r} \text { is the ratio of the } \\
\text { background value of metal } M \text { to the reference } \\
\text { metal } C \text {. } \\
\text { In ER determination, the reference values are } \\
\text { included for normalisation (to compensate for } \\
\text { distortions from geogenic/anthropogenic } \\
\text { activities). } \\
\text { Classification: } \mathrm{EF}<2 \text {, none to minor } \\
\text { enrichment; } 2 \leq \mathrm{EF}<5, \text { moderate enrichment; } \\
5 \leq \mathrm{EF}<10 \text {, significant enrichment; } 10 \leq \mathrm{EF}< \\
25 \text {, severe enrichment; } 25 \leq \mathrm{EF}<50 \text {, very } \\
\text { severe enrichment; } \mathrm{EF}>50, \text { extremely severe } \\
\text { enrichment. }\end{array}$ & $\begin{array}{l}\text { Determination of degree and } \\
\text { status of pollution of } \\
\text { individual HM by natural } \\
\text { and anthropogenic factors. } \\
\text { EF values of } 0.5-1.5 \text { indicate } \\
\text { enrichment from natural } \\
\text { geogenic processes. } \\
\text { EF values > } 1.5 \text { reflect the } \\
\text { influence of anthropogenic } \\
\text { activities on the levels of HM } \\
\text { present. } \\
\text { The use of reference } \\
\text { elemental values makes the } \\
\text { EF index a more reliable } \\
\text { indicator of HM pollution. }\end{array}$ & $\begin{array}{l}\text { S: HM source tracking; reduces HM } \\
\text { variability; estimates anthropogenic } \\
\text { impacts; evaluates pollution impact of } \\
\text { individual metals; precise classification } \\
\text { scale. } \\
\text { W: Relies on reference values; choice of } \\
\text { appropriate geochemical background } \\
\text { critical. }\end{array}$ & {$[272,273,275,280-283]$} \\
\hline 5 & Pollution Load Index (PLI) & $\begin{array}{l}\text { PLI is an empirical pollution indicator } \\
\text { expressed geometrically as a mean (nth root) } \\
\text { of the EF of all the metals evaluated in a } \\
\text { particular site. } \\
\text { PLI for a single site }=\left(\mathrm{EF}_{1} \times \mathrm{EF}_{2} \times \mathrm{EF}_{3} \times \ldots\right. \\
\left.\times \mathrm{EF}_{n}\right)^{1 / n} \text {, where } n \text { is the number of elements } \\
\text { involved. } \\
\text { Classification: PLI }<1 \text {, no or low pollution } \\
\text { level; PLI }=1 \text {, baseline/background pollution; } \\
\text { PLI }>1 \text {, progressive pollution. }\end{array}$ & $\begin{array}{l}\text { Empirical index for } \\
\text { comparative assessment of } \\
\text { environmental pollution. } \\
\text { PLI accounts for the overall } \\
\text { effect of all the HM per site. }\end{array}$ & $\begin{array}{l}\text { S: Combines multiple HM analyses; } \\
\text { easy application and wide usage; } \\
\text { allows site comparison; precise } \\
\text { classification scale available. } \\
\text { D: Omits the influence of natural } \\
\text { geochemical processes; relies on the } \\
\text { geochemical background and EF } \\
\text { values; no account for the availability } \\
\text { of other HM outside the scope of } \\
\text { interest. }\end{array}$ & {$[12,183,210,247,275,280,284]$} \\
\hline
\end{tabular}


Table 2. Cont.

\begin{tabular}{|c|c|c|c|c|c|}
\hline & Index/Factor & Description and Classification & Application & $\begin{array}{l}\text { Strengths (S) and Deficiencies (D) } \\
\text { [260] }\end{array}$ & References \\
\hline 6 & $\begin{array}{l}\text { Potential Ecological Risk } \\
\text { Factor }\left(\mathrm{Er}^{\mathrm{i}}\right)\end{array}$ & 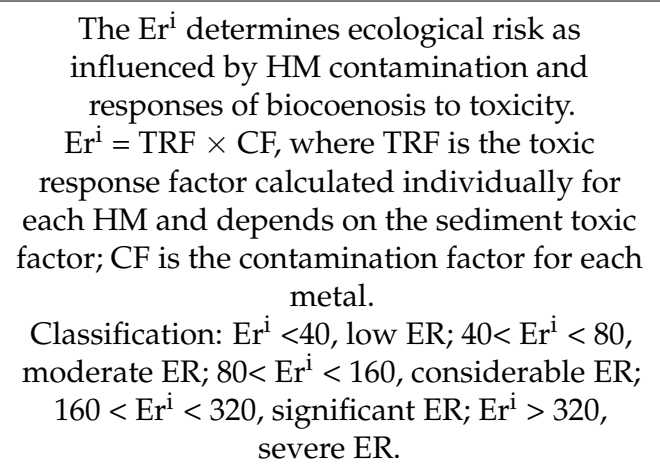 & $\begin{array}{l}\text { Quantitatively estimates the } \\
\text { potential ecological risk of an } \\
\text { environmental contaminant. }\end{array}$ & $\begin{array}{l}\text { S: Widely used; easy application; } \\
\text { accounts for HM impact on biota; } \\
\text { precise classification scale. } \\
\text { D: Relies on CF and TRF estimators for } \\
\text { determination; excludes the potential } \\
\text { availability of other HM in the } \\
\text { environment. }\end{array}$ & {$[68,236,261,263,275,285]$} \\
\hline 7 & $\begin{array}{l}\text { Potential Ecological Risk } \\
\text { Index (PERI) }\end{array}$ & $\begin{array}{l}\text { Summation of all Eri values calculated for a } \\
\text { contaminant in an area. } \\
\text { PERI }=\sum E r^{i}, \text { where } \mathrm{Er}^{\mathrm{i}} \text { is a single index for } \\
\text { each element evaluated. } \\
\text { Classification: PERI }<150, \text { low risk; } 150 \leq \\
\text { PERI }<300 \text {, moderate risk; } 300 \leq \text { PERI }<600 \text {, } \\
\text { high risk; PERI }>600 \text {, significantly high ER. }\end{array}$ & $\begin{array}{l}\text { PERI evaluates the degree of } \\
\text { environmental risks from HM } \\
\text { pollution based on the } \\
\text { sensitivity of biotic } \\
\text { communities to contaminant } \\
\text { concentrations. }\end{array}$ & 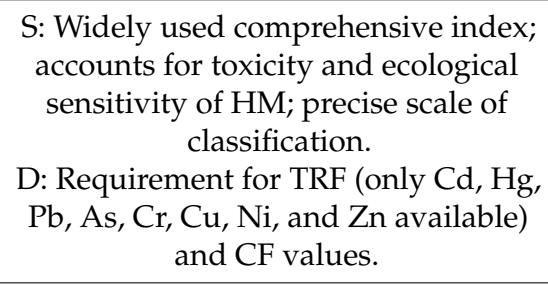 & {$[249,261,263,267,275,286-289]$} \\
\hline 8 & $\begin{array}{l}\text { Combined Pollution Index } \\
\qquad(\mathrm{CPI})\end{array}$ & $\begin{array}{l}\text { A combined PLI (CPI) determines the overall } \\
\text { pollution for all the sites of interest. } \\
\text { CPI for a study area }=\sum \frac{P L I_{k}}{m} \text {, where } P L I_{k} \text { are } \\
\text { the PLI values for } \mathrm{k} \text { sites; } m \text { is the number of } \\
\text { HM considered. }\end{array}$ & $\begin{array}{l}\text { CPI estimates the integrated } \\
\text { pollution status of an area } \\
\text { based on the individual PLI } \\
\text { values. }\end{array}$ & $\begin{array}{l}\text { S: Overall pollution estimator; easy } \\
\text { application. } \\
\text { D: Heavy reliance on other estimators } \\
\text { (TRF, CF, Eri }) \text {; no distinction of } \\
\text { variability due to natural and } \\
\text { anthropogenic influences. }\end{array}$ & {$[183,279,290]$} \\
\hline
\end{tabular}




\subsection{Conceptualisation and Potential Application of AERA in Freshwater Systems of SA}

4.2.1. The Five-Tiered AERA Concept for Aquatic Systema in Degraded Mining Landscapes

Based on the risk hypothesis, the AERA framework is conceptualised around the interrelationships between the risk elements, risk exposure pathways, receptor exposure, endpoint impact measurement, and characterisation of ecological risks in aquatic environments [255]. The aim is to identify and map the potential ecological risks of mining waste, predisposing factors, monitoring mechanisms, and management options for the hazards to aquatic resources in mining-generated wastelands. Hence, a triad approach, modified from the 1998 US Environmental Protection Agency ERA guidelines [258], has been adopted and modified to optimise the potential risks assessment framework for aquatic systems draining these wastelands (Figure 4). The conceptual model defines the risk assessment framework from problem formulation, risk assessment, risk characterisation, and transitions to management decision-making and risk management. These components, further elaborated below, are classified at three main levels: stakeholder engagement in planning, expert(s) participation, and management evaluation and decision-making sessions. These subcomponents are integrated to establish a holistic risk assessment framework that incorporates the key environmental indicators in the three constituents of the aquatic ecosystem matrix: water, sediment, and biota.

\section{Problem Formulation and Risk Hypothesis}

The assessment is on the potential aquatic ecological risks linked to post-mining landscapes. It is hypothesised that there is a high potential ecological risk to the resident biotic communities in aquatic ecosystems due to exposure to particular risk factors, the environmental stressors of potential concern (SOPCs), associated with mining wastelands. Since mine waste elements enter aquatic systems either as a solid flow (e.g., collapsed waste rock pile) or semisolid (e.g., tailings from dams); liquid (e.g., surface mine drainage, contaminated plumes in groundwater, or heap and dump leach); or direct atmospheric fallout (e.g., fugitive dust), the exposure pathways are initially defined. An aquatic ecosystem's risk factors and likely impacts can be physical, chemical, biological, or combined. The representative ecological receptors are the resident aquatic biota exposed to the potential risks at the spatial and temporal scales and can provide "historical evidence" of the SOPCs. The risk questions formulated from this theory are used to address the complete exposure pathways, assessment, and measurement endpoints in risk evaluation and characterisation.

\section{Exposure Assessment}

The potential environmental stressors (SOPCs) are identified by analysing the physicochemical properties of water, sediment, and sediment-associated contaminants (SACs) to quantify contamination levels compared to reference sites and respective quality guidelines. This information is also important in interpreting endpoint ROPC responses to physicochemical environmental fluctuations and stressors. Toxicity tests on streamwater will provide supporting indications of episodic anthropogenic pollution events. Sediment analyses of toxicity determine whether the responses observed in the representative ROPC communities are related to the SACs of concern rather than other multiple environmental risk factors. Water and sediment tests are also employed to discriminate contaminated or impacted sites from the reference sites. 


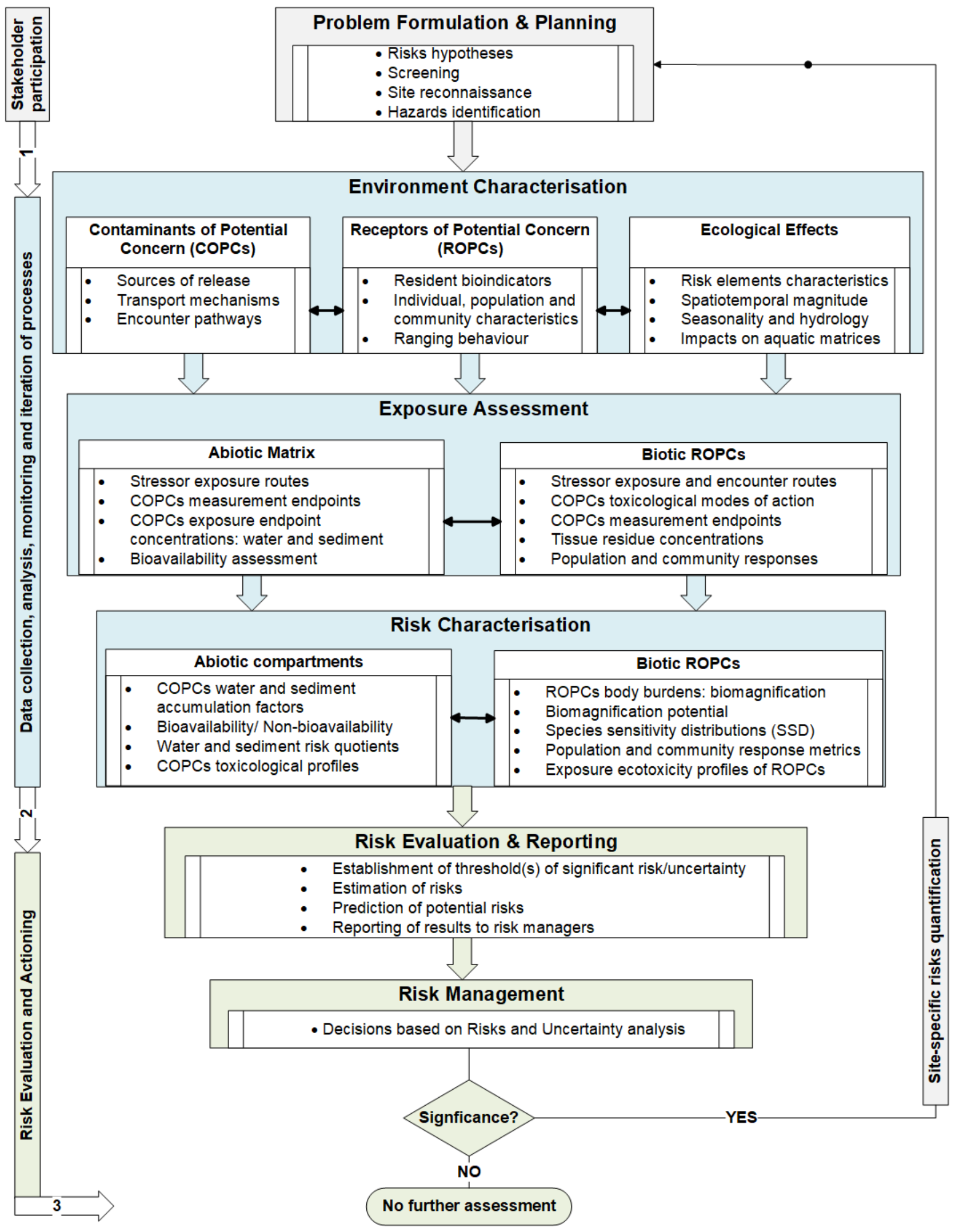

Figure 4. A conceptual framework to assess the potential ecological risks to aquatic systems draining heavy-metal mining landscapes. 


\section{Effects Assessment}

Representative biotic communities serve as bioindicators or receptors of potential contaminants (ROPCs). In addition, the variability in the community structure of benthic ROPCs between impacted and reference sites is used to indicate the biological responses to the spatial and temporal magnitudes of environmental contaminations. The toxicity factors (TFs), body burdens (bioaccumulation), and trophic transfer (biomagnification) profiles of the ROPCs explain the toxicity endpoints or observed effects (OEs) (e.g., growth, mortality, survival, or reproductive rates) on representative receptor populations and community structure [256]. Additionally, sediment-associated contaminants (SACs), biotasediment accumulation factors (BSAFs), and biota-water accumulation factors (BWAFs) are determined to estimate the magnitude and likelihood of SOPC transfer from the abiotic matrix to ROPC populations and communities [254]. The level of SOPCs in the tissues of receptor biota give evidence of the contaminant bioavailability and stressor origin [291] or nonbioavailability [270]. Dissolved SOPCs usually indicate the bioavailability of chemical stressors. However, nonbioavailability does not negate the associated potential risks since the bioaccumulation and biomagnification of toxic materials can be detrimental at higher trophic levels in the aquatic food web.

\section{Risk Characterisation and Sources of Unpredictability}

The characterisation of risks is both on the observed effects (qualitative) and outcomes of different risk quantification methods (e.g., community metrics, biota-water accumulation factors, toxicity factors, and biota-sediment accumulation factors) at predefined "significant risk levels" [255]. The causality between receptor exposure profiles and exposure endpoint effects are derived and employed to develop potential ecological risk index(es). Index development considers the diversity and complexity of aquatic ecosystems, which may increase the unpredictability of the outcomes. The unpredictability of endpoints can arise from uncertainty, measurement and analytical errors, and ignorance or confusion during certain developmental stages (e.g., conceptualisation and risk characterisation) [255]. For instance, uncertainty usually determines the confidence level in developing and applying the indices in a risk management toolkit [212]. An illustration of uncertainty is the spatiotemporal influence on foraging, breeding, or reproduction interdependencies that periodically determine community population dynamics and composition patterns.

Additionally, the presence or absence of a keystone predator(s) or multiple environmental stressors besides the SPOCs under consideration may significantly affect the community characteristics' diversity. Such uncertainties will be factored in during risk description, index development, and the building of risk management scenarios. Variabilities can arise from events (e.g., climate and seasonality) or entities (e.g., stressor properties) that cannot be manipulated, making them indeterminate. Errors can be incurred at any stage in the risk assessment process from design, measurement, sampling, analysis, or the interpretation of data. Efforts are geared towards minimising or estimating potential errors statistically [292]. Ignorance ("unknown unknowns") and confusion due to the complexity of the existing environmental problem(s) may introduce unrecognisable uncertainty during the risk description process [255].

\section{Risk Mitigation and Management}

The assessment outcome provides information on the ecological status, potential risk factors and risks, and mitigation and management options. This process is based on the established comprehensive ecological risks assessment framework for aquatic systems in the mining-generated wastelands. Implications for current and future uses of the impacted sites are clearly defined to enhance the informed judgements for risk mitigation and management. However, decision-making lies with the risk managers and policy managers. Nevertheless, significant uncertainty levels usually warrant site-specific characterisation and further reassessment to develop reevaluated potential risk indices through a step-wise risk assessment iteration process $[17,259]$. 


\section{Rapid Bioassessment Schemes for Management of Aquatic Pollution in Mining Landscapes of SA}

Mangadze et al. [26] and Dallas [293] described several rapid bioassessment schemes (RBS) for aquatic systems developed in SA for specific or integrated assessment objectives. The benefit of the RBS is the potential to rapidly detect changes in the habitat, water chemistry, and the aquatic ecosystem's biotic integrity compared to the reference conditions [293,294]. Different RBS incorporating single or multiple metrics have been developed or applied to monitor aquatic ecosystem health and HM pollution management in most of the mining-impacted river basins of SA (see Table 1). The benthic- and macrophyte-based RBS developed for the region monitoring programs are of particular interest.

\subsection{Congo and Zambezi Basins}

The 2009-2012 integrated Southern Africa River Assessment Scheme (SAFRASS) project resulted in the development of benthic- (diatoms and macroinvertebrates) and macrophyte-based bioassessment protocols for freshwater ecoregions of Zambia [295]. The SAFRASS project derived the ZISS-1 in a survey of benthos; water chemistry ( $\mathrm{pH}$, conductivity, phosphate, and nitrate); and habitat conditions of 95 rivers. The ZISS is based on the SASS model but with an additional six taxa found within Zambia. The efficacy of ZISS lies in its potential to provide a reliable macroinvertebrate-based evaluation of stream integrity in SA.

The macrophyte-based ZMTR was developed from 218 samples comprising 156 macrophyte species alongside water quality determination (SRP, nitrate, $\mathrm{pH}$, alkalinity, and conductivity) to establish the trophic preferences of macrophytes. The ZMTR score was acceptable for an $83 \%$ trophic status of Zambian and 100\% for Botswanan macrophyte samples. Despite the overestimation of low-enriched and overestimation of highly enriched nutrient conditions in impacted streams, ZISS remains a good predictor of the trophic status of SA river systems [226].

Lang et al. [296], under the 2009-2012 SAFRASS multidisciplinary project, assessed the stream integrity using a benthic diatom index (BDI) as a decision support tool for freshwater ecosystem management in SA. A collection of 242 diatom samples from various substrate types in Zambian aquatic ecoregions was used to develop an evidence-based BDI assessment framework for authorities and community-based monitoring programs for tropical SA river systems.

Kaaya et al. [222] developed the Tanzania River Scoring System, TARISS, by readjusting the SASS-5 assessment indicator framework for 96 taxa. The taxa sensitivity distributions were reassigned to simulate the Tanzanian freshwater ecosystem macroinvertebrate biodiversity. The TARISS model reflected higher reliability in disaggregating the stream types. However, the TARISS metric and average score per taxon (ASPT) values were more predictable in response to the stream-site variabilities. A recent study proposed a more simplified and cost-effective macroinvertebrate-based assessment method for Tanzanian rivers [297]. In this scheme, after the pair-wise screening of all the taxa in the existing methods (e.g., TARISS, ZISS, and SASS), four macroinvertebrate orders: Ephemeroptera, Diptera, Odonata, and Trichoptera (EDOT) are suggested for adoption during rapid bioassessments. The EDOT approach simplifies the taxonomic requirements of large datasets and extrapolations of taxa with unrated sensitivity weightings during the development of bioassessment models. Furthermore, the EDOT method requires minimal data consistency, basic taxonomic expertise, and reduces the cost and time demands during the bioassessment exercise. Further testing of the EDOT method is nevertheless required to validate its consistency, reliability, and preference over the SASS-based assessment protocols for tropical African river systems.

Palmer and Taylors [221] based the Namibian scoring system (NASS-2) on SASS-5 using the family-level abundance and composition of macroinvertebrates. The NASS-2 was further expanded to include taxa of Northern Namibia and applied in the Katima 
Mulilo stretch of the Zambezi River. However, seasonal flow regimes highly influenced the NASS-2 bioassessment performance in the Zambezi River ecosystem.

\subsection{Limpopo and Orange-Senqu Basins}

By establishing the national River Ecostatus Monitoring Program (REMP), South Africa has spearheaded the development of flora- and fauna-based RBS in two basins [26,298]. The Chutter $[219,299]$ SASS model has been thoroughly tested and significantly improved to the current version, SASS-5 [189,300-302]. SASS-5 presents improved sampling and analytical procedures with quality controls. Changes were also made on the taxa listing to reflect the South African macroinvertebrate biodiversity. The method's ASPT score remains consistent in the bioassessments across all biotopes, with the highest variability in the gravel-sand-mud biotope. The ASPT score gives a more reliable and consistent assessment of river health. Given the variability between the SASS scores and taxa counts among field personnel, competency-based training is required to ensure consistency in the field application of SASS-5 [189]. Generally, SASS is widely accepted into the pool of RBS for tropical freshwater ecosystems by the scientific community. A mini version of SASS- 5 has been piloted for community-based ecosystem monitoring and participatory management in SA [188]. The miniSASS program is hosted online, and a mobile miniSASS app is available for local communities to monitor and manage freshwater systems in real-time (http:/ / www.minisass.org/en/; accessed on 16 October 2021).

The South African Diatom Index (SADI) was developed based on the European Specific Pollution Index (SPI) to cater for the role of aquatic primary and secondary producer bioindicator communities in RBS during the application of SASS-5 [227]. The SADI provides for the documentation and implementation of diatom biodiversity for ecological monitoring and environmental management. The application of SADI in moderation with the Biological Diatom Index (BDI) has increased the accuracy of diatom-based in SA [228].

The 2005-2009 Botswana Biokavango Freshwater Research Project in the Limpopo Basin developed the Okavango scoring system (OKASS) for aquatic bioassessments. The OKASS incorporates aquatic biota and physicochemical water quality indicators to develop a macroinvertebrate-based biomonitoring index for management purposes [220,303]. Further studies in the delta have explored the possibility of developing similar bioassessment indices for its aquatic systems, e.g., based on the delta's hydrodynamics and habitat peculiarities [304].

\section{Challenges and Opportunities in Implementation of AERA for Mining Landscapes} of SA

\subsection{Challenges}

The unpredictability of climate change impacts, seasonal variability, and hydrological changes on tropical aquatic biodiversity limits their reliability and application for rapid bioassessments. The SA region lacks common networking and knowledgesharing platforms among the national and regional bioassessments, particularly the transboundary river management programs, to synchronise RBS development [298]. Another long-term challenge is the inadequate reference materials or incomplete taxonomic resolution databases for tropical taxa required for index development $[305,306]$. Furthermore, most RBS are biased toward nutrient enrichment and organic pollutants as a proxy for river health, therefore excluding the ecological impact of heavy metals on aquatic biocoenosis $[293,307,308]$.

\subsection{Opportunities}

Despite the existing bottlenecks, there are opportunities to incorporate modern bioassessment technologies to enhance rapid and higher taxonomic resolutions. Molecular environmental DNA/RNA (eDNA/eRNA) technologies have overcome the challenges of conventional bioassessments, allowing for task automation, higher and broader taxonomic precision, and are less invasive [309,310]. However, the eDNA/RNA coding 
and metabarcoding technology should be applied cautiously and supplemented with conventional methods due to the current inherent technicalities during method development, e.g., PCR primer bias and quantitative stage-specific variations in macroinvertebrate biomass [309,311]. Secondly, the development of eDNA/RNA sequencing methods for aquatic biomonitoring and bioassessment should be streamlined through stakeholder and practitioner engagement. The objective is to standardise and optimise the effectiveness of the methods developed. Streamlining can be done in the areas of barcoding and referencing, biotic and metric index development, testing field and lab protocols, data analysis, storage and availability procedures, and knowledge transition at the science-policy interphase [312].

The adoption of community-based monitoring and reporting programs will provide opportunities for increased stakeholder engagement in environmental management. The modification of SASS to the miniSASS has entitled riparian communities to be collectively responsible for environmental conservation of South Africa's river basins [188]. Further, the open-source miniSASS mobile app and the miniSASS website will expand knowledge dissemination and response mechanisms to improve the management of aquatic ecosystems. Similar community-based environmental management programs have been rolled out in other regions of Africa, e.g., the "Adopt A River' citizen science in East Africa [298].

However, in cases where inadequate knowledge, less expertise, and low capacity for rolling out RBS exist, historical physical and chemical methods of characterising aquatic systems can be adopted. More often than not, inorganic parameterisation is either a mandatory baseline or complementary assessment procedure in most environmental monitoring programs [313]. Over time, physical (e.g., turbidity, temperature, and particulate matter) and chemical (e.g., $\mathrm{pH}, \mathrm{EC}$, Eh, oxygen, and organic and inorganic elements) analytical methods have been tested, improved, and standardised, making them universally acceptable for field and laboratory applications. Nevertheless, these techniques require long-term data since they mostly return a "snapshot" scenario of the water physicochemical conditions. Conventional physical and chemical monitoring methods can also be relatively more expensive due to equipment costs, operational logistics, and analytical and data processing requirements than RBS. In contrast, RBS accounts for the historical or long-term cumulative environmental conditions. The sentinel organisms, through biomarkers, display the cumulative impacts of the long-term pollution of aquatic ecosystems [27,191,192,205].

\section{Conclusions}

Aquatic ecosystems are integral to a biosphere's survival since they provide requisite ecosystem goods and services for life. However, these systems are constantly under harmful anthropogenic impacts. For instance, in Southern Africa (SA), the intensification of mining releases heavy metals and metalloids, acid-laden drainage, fallout from acid rain, and solid waste pollutants into its river basins. Therefore, it is necessary to monitor and mitigate these detrimental impacts through established or developed scientifically feasible physical, chemical, or biological methods and integrated assessment systems.

In SA, there is a long-term history of the application of physical and chemical methods in monitoring and managing the pollution of its aquatic systems. Gradually, an integrated approach incorporating inorganic and biomonitoring approaches is becoming more practically sensible and scientifically defensible. Biological methods are gaining popularity due to their robustness, sensitivity, cost-effectiveness, ease of application, and interpretation.

Rapid bioassessment schemes (RBS) have been developed for SA leverage based on the successful South Africa SASS-5 method. However, challenges still exist in aquatic ecosystem monitoring due to the disaggregated approaches in bioassessments. A major gap is the exclusion of heavy-metal (HM) pollutant indicators in the RBS despite the HM constituting a significant source of water pollution in SA. There is also a need to integrate and standardise the existing methodologies, especially taxonomic resolutions for biodiversity assessments. The inclusion of environmental molecular monitoring techniques (eDNA/eRNA) in barcoding and referencing biotic and metric index developments 
would provide long-term benefits in RBS development. Finally, citizenry science is a viable and inclusive approach for collective responsibility and accountability by riparian communities and stakeholders in sustainable river basin management; a classic case is the miniSASS biomonitoring, reporting, and knowledge exchange platform for South Africa's River systems.

Author Contributions: Conceptualization, K.O.O., A.S. and S.S.; methodology, K.O.O. and S.S.; writing — original draft preparation, K.O.O. and S.S.; writing—review and editing, K.O.O., A.S. and S.S.; and supervision, A.S. and S.S. All authors have read and agreed to the published version of the manuscript.

Funding: This review received no external funding, and the APC was funded by the National Science and Technology Council (NSTC) of Zambia.

Acknowledgments: We acknowledge The Copperbelt University Africa Centre for Sustainable Mining (CBU-ACESM) for technical, material, and logistical support.

Conflicts of Interest: The authors declare no conflict of interest. The funders had no role in the design of the study; in the collection, analyses, or interpretation of the data; in the writing of the manuscript; or in the decision to publish the results.

\section{References}

1. Lautze, J.; Phiri, Z.; Smakhtin, V.; Saruchera, D. The Zambezi River Basin: Water and Sustainable Development, 1st ed.; Lautze, J., Phiri, Z., Smakhtin, V., Saruchera, D., Eds.; Routledge: New York, NY, USA, 2017; ISBN 9781315282053.

2. Harrison, I.J.; Brummett, R.; Stiassny, M.L.J. The Wetlands Book II; Springer: Dordrecht, The Netherlands, 2018; ISBN 9789400761735.

3. CRIDF A River Basin View of Southern Africa. Available online: http://cridf.net/cribmap/ (accessed on 9 March 2021).

4. Anhaeusser, C.R.; Maske, S. Mineral Deposits of Southern Africa-Volume I; Geological Society of South Africa: Johannesburg, South Africa, 1986; ISBN 9780620094412.

5. Nriagu, J.O. A History of Global Metal Pollution. Science 1996, 272, 223. [CrossRef]

6. Muma, D.; Besa, B.; Manchisi, J.; Banda, W. Effects of Mining Operations on Air and Water Quality in Mufulira district of Zambia: A Case Study of Kankoyo Township. J. S. Afr. Inst. Min. Metall. 2020, 120, 287-298. [CrossRef]

7. Genthe, B. Post-mining Landscapes (PML) in South Africa. In A CSIR Perspective on South Africa's Mining Landscape; Council for Scientific and Industrial Research, CSIR: Pretoria, South Africa, 2019; pp. 15-22. ISBN 978-0-7988-5641-6.

8. Edwards, D.P.; Sloan, S.; Weng, L.; Dirks, P.; Sayer, J.; Laurance, W.F. Mining and the African environment. Conserv. Lett. 2014, 7, 302-311. [CrossRef]

9. Sako, A.; Nimi, M.; Rein, A. Environmental Geochemistry and Ecological Risk Assessment of Potentially Harmful Elements in Tropical Semi-Arid Soils around the Bagassi South Artisanal Gold Mining Site, Burkina Faso. Cogent Environ. Sci. 2018, 4, 1543565. [CrossRef]

10. Ngole-Jeme, V.M.; Fantke, P. Ecological and Human Health Risks Associated with Abandoned Gold Mine Tailings Contaminated Soil. PLoS ONE 2017, 12, e0172517. [CrossRef] [PubMed]

11. Zengeya, T.A.; Robertson, M.P.; Booth, A.J.; Chimimba, C.T. A Qualitative Ecological Risk Assessment of the Invasive Nile Tilapia, Oreochromis niloticus in a Sub-Tropical African River System (Limpopo River, South Africa). Aquat. Conserv. Mar. Freshw. Ecosyst. 2013, 23, 51-64. [CrossRef]

12. M'kandawire, E.; Choongo, K.; Yabe, J.; Mwase, M.; Saasa, N.; Nakayama, S.M.M.M.; Bortey-Sam, N.; Blindauer, C.A.; Ethel, M.; Choongo, K.; et al. Sediment Metal Contamination in the Kafue River of Zambia and Ecological Risk Assessment. Bull. Environ. Contam. Toxicol. 2017, 99, 108-116. [CrossRef]

13. Forbes, V.E.; Galic, N. Next-generation Ecological Risk Assessment: Predicting Risk from Molecular Initiation to Ecosystem Service Delivery. Environ. Int. 2016, 91, 215-219. [CrossRef]

14. Suter, G.W., II; Norton, S.B. Ecological risk assessment. In Encyclopedia of Ecology; Elsevier B.V.: Washington, DC, USA, 2019; ISBN 9780444641304.

15. Culhane, F.; Teixeira, H.; Nogueira, A.J.A.; Borgwardt, F.; Trauner, D.; Lillebø, A.; Piet, G.; Kuemmerlen, M.; Mcdonald, H.; Higgins, T.O.; et al. Risk to the Supply of Ecosystem Services across Aquatic Ecosystems. Sci. Total Environ. 2019, 660, 611-621. [CrossRef]

16. Teixeira, H.; Lillebø, A.I.; Culhane, F.; Robinson, L.; Trauner, D.; Borgwardt, F.; Kummerlen, M.; Barbosa, A.; McDonald, H.; Funk, A.; et al. Linking Biodiversity to Ecosystem Services Supply: Patterns across Aquatic Ecosystems. Sci. Total Environ. 2019, 657, 517-534. [CrossRef] [PubMed]

17. Bartell, S.M. Ecological risk assessment and sustainable environmental management. In Interconnections Between Human and Ecosystem Health; Di Giulio, R.T., Monosson, E., Eds.; Springer: Dordrecht, The Netherlands, 1996; pp. 159-179. 
18. Gevorgyan, G.; Mamyan, A.; Hambaryan, L.; Khudaverdyan, S.; Vaseashta, A. Environmental Risk Assessment of Heavy Metal Pollution in Armenian River Ecosystems: Case Study of Lake Sevan and Debed River Catchment Basins. Polish J. Environ. Stud. 2016, 25, 2387-2399. [CrossRef]

19. Karr, J.R. Ecological health indicators. In Encyclopedia of Ecology, Five-Volume Set; Elsevier: Amsterdam, The Netherlands, 2008; pp. 1037-1041. ISBN 9780080914565.

20. Niemi, G.J.; McDonald, M.E. Application of Ecological Indicators. Annu. Rev. Ecol. Evol. Syst. 2004, 35, 89-111. [CrossRef]

21. Ney, R.E. Where did that Chemical Go? A Practical Guide to Chemical Fate and Transport in the Environment; Van Nostrand Reinhold: New York, NY, USA, 1990; ISBN 0442004575.

22. Hunt, C.F.; Voulvoulis, N. Chemical pollution of the aquatic environment and health. In Environmental Pollutant Exposures and Public Health; Harrison, R.M., Ed.; The Royal Society of Chemistry: Cambridge, UK, 2020; pp. 39-69. ISBN 978-1-78801-895-1.

23. Kuemmerlen, M.; Reichert, P.; Siber, R.; Schuwirth, N. Ecological Assessment of River Networks: From Reach to Catchment Scale. Sci. Total Environ. 2019, 650, 1613-1627. [CrossRef]

24. López, E.; Patiño, R.; Vázquez-Sauceda, M.L.; Pérez-Castañeda, R.; Arellano-Méndez, L.U.; Ventura, R.; Heyer, L. Water Quality and Ecological Risk Assessment of Intermittent Streamflow through Mining and Urban Areas of San Marcos River Sub-Basin, Mexico. Environ. Nanotechnol. Monit. Manag. 2020, 14, 100369. [CrossRef]

25. Verdonschot, P.F.M. Integrated Ecological Assessment Methods as a Basis for Sustainable Catchment Management. Hydrobiologia 2000, 422, 389-412. [CrossRef]

26. Mangadze, T.; Dalu, T.; William, F.P. Biological Monitoring in Southern Africa: A Review of the Current Status, Challenges and Future Prospects. Sci. Total Environ. 2019, 648, 1492-1499. [CrossRef] [PubMed]

27. Li, L.; Zheng, B.; Liu, L. Biomonitoring and Bioindicators used for River Ecosystems: Definitions, Approaches and Trends. Procedia Environ. Sci. 2010, 2, 1510-1524. [CrossRef]

28. Sharaky, A.M. Mineral resources and exploration in Africa. In Proceedings of the Conference of 25th Revolution and the Future of the Relationships between Egypt and Nile Basin Countries; Department of Natural Resources, Institute of African Research and Studies, Cairo University: Cairo, Egpyt, 2011; Volume 2011, pp. 1-20.

29. MA Mining in Africa: Facts. Available online: https: / / www.miningafrica.net/ (accessed on 18 March 2021).

30. Reichl, C.; Schatz, M.; Zsak, G. World Mining Data 2020: Iron and Ferro-Alloy Metals, Non-Ferrous Metals, Precious Metals, Industrial Minerals, and Mineral Fuels; Federal Ministry of Science, Research and Economy: Vienna, Austria, 2020; Volume 35, ISBN 3456-634767568.

31. Foster, R.P. Mineral Deposits of Africa 1907-2016. Soc. Econ. Geol. 2016, 1, 1-8.

32. UNECA-AUC. Africa Mining Vision; United Nations Economic Commission for Africa \& African Union Commission: Addis Ababa, Ethiopia, 2009.

33. ZCM. The 10-Year Miracle: The Story of Mining in North-Western Province; Zambia Chamber of Mines: Lusaka, Zambia, 2018.

34. Harrison, P.; Zack, T. The Power of Mining: The Fall of Gold and Rise of Johannesburg. J. Contemp. Afr. Stud. 2012, 30, 551-570. [CrossRef]

35. IFC. Sustainable and Responsible Mining in Africa-A Getting Started Guide; International Finance Corporation, World Bank Group: Nairobi, Kenya, 2014.

36. Marara, T.; Palamuleni, L.G. An Environmental Risk Assessment of the Klip River using Water Quality Indices. Phys. Chem. Earth Parts A/B/C 2019, 114, 102799. [CrossRef]

37. Mwaanga, P.; Silondwa, M.; Kasali, G.; Banda, P.M. Preliminary Review of Mine Air Pollution in Zambia. Heliyon 2019 , 5, e02485. [CrossRef]

38. Kapungwe, E.M. Heavy Metal Contaminated Water, Soils and Crops in Peri Urban Wastewater Irrigation Farming in Mufulira and Kafue Towns in Zambia. J. Geogr. Geol. 2013, 5, 55-72. [CrossRef]

39. Ahmed, A.I.; Bryant, R.G.; Edwards, D.P. Where are Mines located in Sub-Saharan Africa and How have they Expanded Over Time? L. Degrad. Dev. 2021, 32, 112-122. [CrossRef]

40. Starke, L. (Ed.) ICMM Good Practice Guidance for Mining and Biodiversity; International Council on Mining and Metals: London, UK, 2006; ISBN 0954995481.

41. Danoucaras, N.; Vink, S.; Bansuan, A. Water Issues Associated with Mining in Developing Countries: Action Research Report; International Mining for Development Centre (IM4DC): Perth, Australia, 2012.

42. Durand, J.F. The Impact of Gold Mining on the Witwatersrand on the Rivers and Karst System of Gauteng and North West Province, South Africa. J. Afr. Earth Sci. 2012, 68, 24-43. [CrossRef]

43. Atibu, E.K.; Devarajan, N.; Laffite, A.; Giuliani, G.; Salumu, J.A.; Muteb, R.C.; Mulaji, C.K.; Otamonga, J.-P.; Elongo, V.; Mpiana, P.T.; et al. Assessment of Trace Metal and Rare Earth Elements Contamination in Rivers Around Abandoned and Active Mine areas: The Case of Lubumbashi River and Tshamilemba Canal, Katanga, Democratic Republic of the Congo. Geochemistry 2016, 76, 353-362. [CrossRef]

44. Nachiyunde, K. Assessment of Dissolved Heavy Metal Pollution in Five Provinces of Zambia. J. Environ. Prot. 2013, 4, 80-85. [CrossRef]

45. Fayiga, A.O.; Ipinmoroti, M.O.; Chirenje, T. Environmental Pollution in Africa. Environ. Dev. Sustain. 2018, 20, 41-73. [CrossRef] 
46. Ashton, P.J.; Love, D.; Mahachi, H.; Dirks, P.G.H.M. An Overview of the Impact of Mining and Mineral Processing Operations on Water Resources and Water Quality in the Zambezi, Limpopo and Olifants Catchments in Southern Africa: Contract Report to the Mining, Minerals and Sustainable Development Project; CSIREnvironmentek, Pretoria, South Africa and Geology Department, University of Zimbabwe, Harare, Zimbabwe: Pretoria, South Africa; CSIREnvironmentek, Pretoria, South Africa and Geology Department, University of Zimbabwe, Harare, Zimbabwe: Harare, Zimbabwe, 2001.

47. Yabe, J.; Ishizuka, M.; Umemura, T. Current Levels of Heavy Metal Pollution in Africa. J. Vet. Med. Sci. 2010, 72, 1257-1263. [CrossRef]

48. SADC. SADC Statistical Yearbook 2015, 5th ed.; SADC: Gaborone, Botswana, 2016.

49. SADC Southern African Development Community Natural Resources: Water. Available online: https://sadc.int/themes/naturalresources/water/ (accessed on 9 March 2021).

50. Regina, N.-M.M. Biological Monitoring and Pollution Assessment of the Mukuvisi River, Harare, Zimbabwe. Lakes Reserv. Sci. Policy Manag. Sustain. Use 2012, 17, 73-80. [CrossRef]

51. FAO. FAO GeoNetwork: The Portal to Spatial Data and Information. Available online: http://www.fao.org/geonetwork/srv/ en/metadata.show?id=37038\&currTab=simple (accessed on 17 March 2021).

52. Masindi, V.; Muedi, K.L. Environmental contamination by heavy metals. In Heavy Metals; IntechOpen: Rijeka, Croatia, 2018; pp. $115-133$.

53. Tanor, E.B.; Tsénoli, S.; George, M. J. Physico-chemical Assessment of Pollution in the Caledon River Around Maseru City, Lesotho. Eur. Chem. Bull. 2014, 3, 776-782.

54. Iloms, E.; Ololade, O.O.; Ogola, H.J.O.; Selvarajan, R. Investigating Industrial Effluent Impact on Municipal Wastewater Treatment Plant in Vaal, South Africa. Int. J. Environ. Res. Public Health 2020, 17, 1096. [CrossRef]

55. Olaniran, A.O.; Naicker, K.; Pillay, B. Assessment of Physico-chemical Qualities and Heavy Metal Concentrations of Umgeni and Umdloti Rivers in Durban, South Africa. Environ. Monit. Assess. 2014, 186, 2629-2639. [CrossRef] [PubMed]

56. Nde, S.; Mathuthu, M. Assessment of Potentially Toxic Elements as Non-Point Sources of Contamination in the Upper Crocodile Catchment Area, North-West Province, South Africa. Int. J. Environ. Res. Public Health 2018, 15, 576. [CrossRef]

57. McCartney, M.; Beilfuss, R.D.; Rebelo, L.-M. Zambezi river basin. In The Wetland Book II: Distribution, Description, and Conservation; Springer: Dordrecht, The Netherlands, 2018; Volume 2, pp. 1217-1232.

58. Taylor, M.P.; Kesterton, R.G.H. Heavy Metal Contamination of an Arid River Environment: Gruben River, Namibia. Geomorphology 2002, 42, 311-327. [CrossRef]

59. Ravengai, S.; Love, D.; Love, I.; Gratwicke, B.; Mandingaisa, O.; Owen, R. Impact of Iron Duke Pyrite Mine on Water Chemistry and Aquatic Life-Mazowe Valley, Zimbabwe. Water SA 2007, 31, 219. [CrossRef]

60. Love, D.; Ravengai, S.; Lupankwa, K.; Mabvira-meck, M.; Musiwa, K.; Owen, R. Challenges of Surface Water Quality Management in Mining in the Zambezi Basin, Zimbabwe: Synopsis and Case Studies, In Proceedings of the 9th Water Institute of South Africa (WISA) Biennial Conference, ICC, Durban, South Africa, 21-25 May 2006.

61. Huang, Y.; Zhou, B.; Li, N.; Li, Y.; Han, R.; Qi, J.; Lu, X.; Li, S.; Feng, C.; Liang, S. Spatial-Temporal Analysis of Selected Industrial Aquatic Heavy Metal Pollution in China. J. Clean. Prod. 2019, 238, 117944. [CrossRef]

62. Ikenaka, Y.; Nakayama, S.M.M.; Muzandu, K.; Choongo, K.; Teraoka, H.; Mizuno, N.; Ishizuka, M. Heavy Metal Contamination of Water and Soil. Afr. J. Environ. Sci. Technol. 2010, 4, 729-739.

63. Ettler, V.; Štěpánek, D.; Mihaljevič, M.; Drahota, P.; Jedlicka, R.; Kříbek, B.; Vaněk, A.; Penížek, V.; Sracek, O.; Nyambe, I. Slag Dusts from Kabwe (Zambia): Contaminant Mineralogy and Oral Bioaccessibility. Chemosphere 2020, 260, 127642. [CrossRef]

64. Tembo, B.D.; Sichilongo, K.; Cernak, J. Distribution of Copper, Lead, Cadmium and Zinc Concentrations in Soils Around Kabwe Town in Zambia. Chemosphere 2006, 63, 497-501. [CrossRef] [PubMed]

65. Nakayama, S.M.M.; Ikenaka, Y.; Hamada, K.; Muzandu, K.; Choongo, K.; Teraoka, H.; Mizuno, N.; Ishizuka, M. Metal and Metalloid Contamination in Roadside Soil and Wild Rats Around a Pb-Zn Mine in Kabwe, Zambia. Environ. Pollut. 2011, 159, 175-181. [CrossRef]

66. Sracek, O.; Kříbek, B.; Mihaljevič, M.; Majer, V.; Veselovský, F.; Vencelides, Z.; Nyambe, I. Mining-related Contamination of Surface Water and Sediments of the Kafue River Drainage System in the Copperbelt District, Zambia: An Example of a High Neutralization Capacity System. J. Geochem. Explor. 2012, 112, 174-188. [CrossRef]

67. Kambole, M.S. Managing the Water Quality of the Kafue River. Phys. Chem. Earth Parts A/B/C 2003, 28, 1105-1109. [CrossRef]

68. Vu, C.T.; Lin, C.; Shern, C.-C.; Yeh, G.; Le, V.G.; Tran, H.T. Contamination, Ecological Risk and Source Apportionment of Heavy Metals in Sediments and Water of a Contaminated River in Taiwan. Ecol. Indic. 2017, 82, 32-42. [CrossRef]

69. Motuzova, G.V.; Minkina, T.M.; Karpova, E.A.; Barsova, N.U.; Mandzhieva, S.S. Soil Contamination with Heavy Hetals as a Potential and Real Risk to the Environment. J. Geochem. Explor. 2014, 144, 241-246. [CrossRef]

70. Diami, S.M.; Kusin, F.M.; Madzin, Z. Potential Ecological and Human Health Risks of Heavy Metals in Surface Soils Associated with Iron Ore Mining in Pahang, Malaysia. Environ. Sci. Pollut. Res. 2016, 23, 21086-21097. [CrossRef] [PubMed]

71. Sracek, O.; Kříbek, B.; Mihaljevič, M.; Ettler, V.; Vaněk, A.; Penížek, V.; Filip, J.; Veselovský, F.; Nyambe, I. The Impact of Wetland on Neutral Mine Drainage from Mining Wastes at Luanshya in the Zambian Copperbelt in the Framework of Climate Change. Environ. Sci. Pollut. Res. 2018, 25, 28961-28972. [CrossRef] 
72. Syakalima, M.S.; Choongo, K.C.; Chilonda, P.; Ahmadu, B.; Mwase, M.; Onuma, M.; Sugimoto, C.; Tsubota, T.; Fukushi, H.; Yoshida, M.; et al. Bioaccumulation of Lead in Wildlife Dependent on the Contaminated Environment of the Kafue Flats. Bull. Environ. Contam. Toxicol. 2001, 67, 438-445. [CrossRef] [PubMed]

73. Norrgren, L.; Pettersson, U.; Örn, S.; Bergqvist, P.A. Environmental Monitoring of the Kafue River, Located in the Copperbelt, Zambia. Arch. Environ. Contam. Toxicol. 2000, 38, 334-341. [CrossRef] [PubMed]

74. Shandro, J.A.; Veiga, M.M.; Chouinard, R. Reducing Mercury Pollution from Artisanal Gold Mining in Munhena, Mozambique. J. Clean. Prod. 2009, 17, 525-532. [CrossRef]

75. Dondeyne, S.; Ndunguru, E.; Rafael, P.; Bannerman, J. Artisanal Mining in Central Mozambique: Policy and Environmental Issues of Concern. Resour. Policy 2009, 34, 45-50. [CrossRef]

76. Gutu, A. Artisanal and Small-scale Mining in Zimbabwe-Curse or Blessing? Parliament of Zimbabwe: Harare, Zimbabwe, 2017; Volume 2.

77. Mujere, N.; Isidro, M. Impacts of artisanal and small-scale gold mining on water quality in mozambique and zimbabwe. In Impact of Water Pollution on Human Health and Environmental Sustainability; McKeown, E., Bugyi, G., Eds.; IGI Global: Hershey, PA, USA, 2016; ISBN 9781466695603.

78. de Pereira, Â.J. Environmental Impact of Artisanal Gold Mining in the Pungwe River Basin. FOG-Freib. Online Geosci. 2009, 24, 45-47.

79. $\quad$ Drace, K.; Kiefer, A.M.; Veiga, M.M.; Williams, M.K.; Ascari, B.; Knapper, K.A.; Logan, K.M.; Breslin, V.M.; Skidmore, A.; Bolt, D.A.; et al. Mercury-free, Small-Scale Artisanal Gold Mining in Mozambique: Utilization of Magnets to Isolate Gold at Clean Tech Mine. J. Clean. Prod. 2012, 32, 88-95. [CrossRef]

80. MIREM/UNIZAMBEZE. The Problems of Artisanal Gold Mining in Manica Province; MIREM/UNIZAMBEZE: Maputo, Mozambique, 2012.

81. Dalu, T.; Sachikonye, M.T.B.; Alexander, M.E.; Dube, T.; Froneman, W.P.; Manungo, K.I.; Bepe, O.; Wasserman, R.J. Ecological Assessment of Two Species of Potamonautid Freshwater Crabs from the Eastern Highlands of Zimbabwe, with Implications for Their Conservation. PLoS ONE 2016, 11, 1-17. [CrossRef] [PubMed]

82. Meck, M.L.; Atlhopheng, J.; Masamba, W.R.L.; Ringrose, S. Pollution Implications of Save River Water from Weathering and Dissolution of Metal-Hosting Minerals at Dorowa Phosphate mine, Zimbabwe. Phys. Chem. Earth Parts A/B/C 2010, 35, 679-685. [CrossRef]

83. Meck, M.L.; Atlhopheng, J.; Masamba, W.R.L. Current Impact of Mining Alkaline Rocks on Save River Water Quality in Zimbabwe. J. Afr. Earth Sci. 2009, 55, 58-62. [CrossRef]

84. Dalu, T.; Wasserman, R.J.; Tonkin, J.D.; Alexander, M.E.; Dalu, M.T.B.; Motitsoe, S.N.; Manungo, K.I.; Bepe, O.; Dube, T. Assessing Drivers of Benthic Macroinvertebrate Community Structure in African Highland Streams: An Exploration Using Multivariate Analysis. Sci. Total Environ. 2017, 601-602, 1340-1348. [CrossRef] [PubMed]

85. ZELA. Report on the Scientific Investigation of the Impact of Marange Diamond Mining Operations on Water Quality in the Save and Odzi Rivers: Including Assessment of the Health, Environmental and Livelihoods Impacts; Zimbabwe Environmental Law Association, ZELA: Harare, Zimbabwe, 2012.

86. Marr, S.M.; Jooste, A.; Addo-Bediako, A.; Luus-Powell, W.J. Are Catfish from Metal-Polluted Impoundments in the Olifants River, South Africa, Safe for Human Consumption? Inl. Waters 2015, 5, 215-223. [CrossRef]

87. Riddell, E.S.; Govender, D.; Botha, J.; Sithole, H.; Petersen, R.M.; Shikwambana, P. Pollution Impacts on the Aquatic Ecosystems of the Kruger National Park, South Africa. Sci. Afr. 2019, 6, e00195. [CrossRef]

88. Addo-Bediako, A. Assessment of Heavy Metal Pollution in the Blyde and Steelpoort Rivers of the Olifants River System, South Africa. Polish J. Environ. Stud. 2020, 29, 3023-3029. [CrossRef]

89. DWAF. South African Water Quality Guidelines. Volume 7: Aquatic Ecosystems; Department of Water Affairs and Forestry (DWAF): Pretoria, South Africa, 1996.

90. Edokpayi, J.N.; Odiyo, J.; Popoola, O.; Msagati, T. Assessment of Trace Metals Contamination of Surface Water and Sediment: A Case Study of Mvudi River, South Africa. Sustainability 2016, 8, 135. [CrossRef]

91. Addo-Bediako, A.; Marr, S.M.; Jooste, A.; Luus-Powell, W.J. Are Metals in the Muscle Tissue of MozambiqueTtilapia a Threat to Human Health? A Case Study of Two Impoundments in the Olifants River, Limpopo Province, South Africa. Ann. Limnol. 2014, 50, 201-210. [CrossRef]

92. Wolmarans, C.T.; Kemp, M.; de Kock, K.N.; Roets, W.; van Rensburg, L.; Quinn, L. A Semi-Quantitative Survey of Macroinvertebrates at Selected Sites to Evaluate the Ecosystem Health of the Olifants River. Water SA 2014, 40, 245-254. [CrossRef]

93. Edokpayi, J.N.; Odiyo, J.O.; Olasoji, S.O. Assessment of Heavy Metal Contamination of Dzindi River, in Limpopo province, South Africa. Int. J. Nat. Sci. Res. 2014, 2, 185-194.

94. Phiri, C. An Assessment of the Health of Two Rivers within Harare, Zimbabwe, on the Basis of Macroinvertebrate Community Structure and Selected Physicochemical Variables. Afr. J. Aquat. Sci. 2000, 25, 134-145. [CrossRef]

95. Dube, T.; Chibanda, M.; Manhire, B.; Rutanhira, C.; Mabugu, C.; Makaka, C.; Makaure, J.; Muteveri, T. Sewage Effluent Causes Metal Pollution of a Sub-Tropical River System in Zimbabwe. Bull. Environ. Contam. Toxicol. 2020, 104, 339-344. [CrossRef]

96. Greenfield, R.; van Vuren, J.H.J.; Wepener, V. Heavy Metal Concentrations in the Water of the Nyl River System, South Africa. Afr. J. Aquat. Sci. 2012, 37, 219-224. [CrossRef] 
97. ORASECOM. Overview of the Orange-Senqu River Basin-Orange-Senqu River Commission (ORASECOM). Available online: http:/ / www.orasecom.org/about/orangesenqu+basin.aspx (accessed on 31 March 2021).

98. UNDP-GEF. POPs, PAHs and Elemental Levels in Sediment, Fish and Wild Bird Eggs in the Orange-Senqu River Basin: Final Report; UNDP-GEF: Guateng, South Africa, 2011.

99. Moloi, M.; Ogbeide, O.; Voua Otomo, P. Probabilistic Health Risk Assessment of Heavy Metals at Wastewater Discharge Points within the Vaal River Basin, South Africa. Int. J. Hyg. Environ. Health 2020, 224, 113421. [CrossRef] [PubMed]

100. Moyo, N.A.G.; Rapatsa, M.M. Trace Metal Contamination and Risk Assessment of an Urban River in Limpopo Province, South Africa. Bull. Environ. Contam. Toxicol. 2019, 102, 492-497. [CrossRef]

101. Chetty, S.; Pillay, L. Assessing the Influence of Human Activities on River Health: A Case for Two South African Rivers with Differing Pollutant Sources. Environ. Monit. Assess. 2019, 191, 168. [CrossRef]

102. Mukurunge, T.; Bhila, T. Impacts of Mining Operations on Water Resources and Ecosystems: The Case of Letseng Diamonds in Lesotho. Int. J. Sci. Res. Dev. 2019, 6, 634-640.

103. Gibbs, A.; Gibbs, T. A Water Supply and Pollution Crisis in Lesotho's Textile Factories: The Problems of Footloose Investment; Natal, South Africa, 2003. Available online: https:/ / ccs.ukzn.ac.za/files/Lesotho\%20Water\%20-\%20Final.pdf (accessed on 3 June 2021).

104. Ntengwe, F.W.; Maseka, K.K. The Impact of Effluents Containing Zinc and Nickel Metals on Stream and River Water Bodies: The Case of Chambishi and Mwambashi Streams in Zambia. Phys. Chem. Earth Parts A/B/C 2006, 31, 814-820. [CrossRef]

105. Netshiongolwe, N.R.; Cuthbert, R.N.; Maenetje, M.M.; Chari, L.D.; Motitsoe, S.N.; Wasserman, R.J.; Munyai, L.F.; Dalu, T. Quantifying Metal Contamination and Potential Uptake by Phragmites australis Adans. (Poaceae) Along a Subtropical River System. Plants 2020, 9, 846. [CrossRef]

106. Dudgeon, D.; Arthington, A.H.; Gessner, M.O.; Kawabata, Z.-I.I.; Knowler, D.J.; Lévêque, C.; Naiman, R.J.; Prieur-Richard, A.-H.H.; Soto, D.; Stiassny, M.L.J.J.; et al. Freshwater Biodiversity: Importance, Threats, Status and Conservation Challenges. Biol. Rev. 2006, 81, 163-182. [CrossRef] [PubMed]

107. Sonter, L.J.; Ali, S.H.; Watson, J.E.M. Mining and Biodiversity: Key Issues and Research Needs in Conservation Science. Proc. R. Soc. B Biol. Sci. 2018, 285, 20181926. [CrossRef] [PubMed]

108. UNEP-WCMC. The State of Biodiversity in Africa: A Mid-Term Review of Progress Towards the Aichi Biodiversity Targets; UNEP-WCMC: Cambridge, UK, 2016; ISBN 9789280735086.

109. Herbst, D.B. Establishing Reference Conditions for Streams and Measuring Ecological Responses to Management Actions Using Aquatic Invertebrate Biological Assessments; Pacific Southwest Research Station, Forest Service, US Department of Agriculture: Albany, CA, USA, 2004.

110. WDC. Diamond Mining and the Environment Fact Sheet; World Diamond Council: New York, NY, USA, 2016.

111. Lake, P.S. Ecological Effects of Perturbation by Drought in Flowing Waters. Freshw. Biol. 2003, 48, 1161-1172. [CrossRef]

112. Boulton, A.J. Parallels and Contrasts in the Effects of Drought on Stream Macroinvertebrate Assemblages. Freshw. Biol. 2003, 48, 1173-1185. [CrossRef]

113. Ranasinghe, R.; Wu, C.S.; Conallin, J.; Duong, T.M.; Anthony, E.J. Disentangling the Relative Impacts of Climate Change and Human Activities on Fluvial Sediment Supply to the Coast by the World's Large Rivers: Pearl River Basin, China. Sci. Rep. 2019, 9, 9236. [CrossRef] [PubMed]

114. Park, I.; Tabelin, C.B.; Jeon, S.; Li, X.; Seno, K.; Ito, M.; Hiroyoshi, N. A Review of Recent Strategies for Acid Mine Drainage Prevention and Mine tailings Recycling. Chemosphere 2019, 219, 588-606. [CrossRef] [PubMed]

115. Kaur, H.; Girdhar, M.; Mohan, A. Acid Mine Drainage: An Introduction and Treatment Strategies. Pollut. Res. 2018, 37, S82-S90.

116. Ettler, V.; Mihaljevič, M.; Šebek, O.; Molek, M.; Grygar, T.; Zeman, J. Geochemical and Pb Isotopic Evidence for Sources and Dispersal of Metal Contamination in Stream Sediments from the Mining and Smelting District of Př́bram, Czech Republic. Environ. Pollut. 2006, 142, 409-417. [CrossRef]

117. Ettler, V.; Cihlová, M.; Jarošíková, A.; Mihaljevič, M.; Drahota, P.; Kříbek, B.; Vaněk, A.; Penížek, V.; Sracek, O.; Klementová, M.; et al. Oral Bioaccessibility of Metal(loid)s in Dust Materials from Mining Areas of Northern Namibia. Environ. Int. 2019, 124, 205-215. [CrossRef]

118. Méndez-García, C.; Peláez, A.I.; Mesa, V.; Sánchez, J.; Golyshina, O.V.; Ferrer, M. Microbial Diversity and Metabolic Networks in Acid Mine Drainage Habitats. Front. Microbiol. 2015, 6, 475. [CrossRef]

119. Simmons, J.A.; Lawrence, E.R.; Jones, T.G. Treated and Untreated Acid Mine Drainage Effects on Stream Periphyton Biomass, Leaf Decomposition, and Macroinvertebrate Diversity. J. Freshw. Ecol. 2005, 20, 413-424. [CrossRef]

120. Hogsden, K.L.; Harding, J.S. Consequences of Acid Mine Drainage for the Structure and Function of Benthic Stream Communities: A Review. Freshw. Sci. 2012, 31, 108-120. [CrossRef]

121. Kim, J.-Y.; Lee, B.-T.; Shin, K.-H.; Lee, K.-Y.; Kim, K.-W.; An, K.-G.; Park, Y.-S.; Kim, J.-Y.; Kwon, Y.-H. Ecological Health Assessment and Remediation of the Stream Impacted by Acid Mine Drainage of the Gwangyang Mine Area. Environ. Monit. Assess. 2007, 129, 79-85. [CrossRef]

122. Hussain, S.; Sultana, T.; Sultana, S.; Hussain, B.; Mahboob, S.; Al-Ghanim, K.A.; Riaz, M.N. Seasonal Monitoring of River through Heavy Metal Bioaccumulation and Histopathological Alterations in Selected Fish Organs. J. King Saud Univ.-Sci. 2021, $33,101626$. [CrossRef] 
123. Rubalingeswari, N.; Thulasimala, D.; Giridharan, L.; Gopal, V.; Magesh, N.S.; Jayaprakash, M. Bioaccumulation of Heavy Metals in Water, Sediment, and Tissues of Major Fisheries from Adyar Estuary, South-East Coast of India: An Ecotoxicological Impact of a Metropolitan City. Mar. Pollut. Bull. 2021, 163, 111964. [CrossRef] [PubMed]

124. Govind, P. Heavy Metals Causing Toxicity in Animals and Fishes. Res. J. Anim. Res. J. Anim. Vet. Fish. Sci. Int. Sci. Congr. Assoc. 2014, 2, 17-23.

125. Huseen, H.M.; Mohammed, A.J. Heavy Metals Causing Toxicity in Fishes. J. Phys. Conf. Ser. 2019, 1294, 062028. [CrossRef]

126. Avigliano, E.; Schenone, N.F.; Volpedo, A.V.; Goessler, W.; Fernández Cirelli, A. Heavy Metals and Trace Elements in Muscle of Silverside (Odontesthes bonariensis) and Water from Different Environments (Argentina): Aquatic Pollution and Consumption Effect Approach. Sci. Total Environ. 2015, 506-507, 102-108. [CrossRef]

127. Cusnir, R.; Steinmann, P.; Bochud, F.; Froidevaux, P. A DGT Technique for Plutonium Bioavailability Measurements. Environ. Sci. Technol. 2014, 48, 10829-10834. [CrossRef]

128. Traina, S.J.; Laperche, V.V. Contaminant Bioavailability in Soils, Sediments, and Aquatic Environments. Proc. Natl. Acad. Sci. USA 1999, 96, 3365-3371. [CrossRef]

129. Xie, S.; Ma, Y.; Strong, P.J.; Clarke, W.P. Fluctuation of Dissolved Heavy Metal Concentrations in the Leachate from Anaerobic Digestion of Municipal Solid Waste in Commercial Scale Landfill Bioreactors: The Effect of $\mathrm{pH}$ and Associated Mechanisms. J. Hazard. Mater. 2015, 299, 577-583. [CrossRef]

130. Haus, N.; Zimmermann, S.; Wiegand, J.; Sures, B. Occurrence of Platinum and Additional Traffic Related Heavy Metals in Sediments and Biota. Chemosphere 2007, 66, 619-629. [CrossRef]

131. Ma, T.; Gong, S.; Tian, B. Effects of Sediment-associated CuO Nanoparticles on Cu Bioaccumulation and Oxidative Stress Responses in Freshwater Snail, Bellamya aeruginosa. Sci. Total Environ. 2017, 580, 797-804. [CrossRef]

132. Jeppe, K.J.; Yang, J.; Long, S.M.; Carew, M.E.; Zhang, X.; Pettigrove, V.; Hoffmann, A.A. Detecting Copper Toxicity in Sediments: From the Subindividual Level to the Population Level. J. Appl. Ecol. 2017, 54, 1331-1342. [CrossRef]

133. Giddings, J.M.; Williams, W.M.; Solomon, K.R.; Giesy, J.P. Risks to aquatic organisms from use of chlorpyrifos in the United States. In Reviews of Environmental Contamination and Toxicology; Giesy, J.P., Solomon, K.R., Eds.; Springer: Berlin/Heidelberg, Germany, 2014; pp. 119-162.

134. Rainbow, P.S.; Luoma, S.N. Metal Toxicity, Uptake and Bioaccumulation in Aquatic Invertebrates-Modelling Zinc in Crustaceans. Aquat. Toxicol. 2011, 105, 455-465. [CrossRef]

135. Núñez, S.E.R.; Negrete, J.L.M.; Rios, J.E.A.; Hadad, H.R.; Maine, M.A. Hg, Cu, Pb, Cd, and Zn Accumulation in Macrophytes Growing in Tropical Wetlands. Water. Air. Soil Pollut. 2011, 216, 361-373. [CrossRef]

136. Tchounwou, P.B.; Yedjou, C.G.; Patlolla, A.K.; Sutton, D.J. Heavy metal toxicity and the environment. In Molecular, Clinical and Environmental Toxicology; Luch, A., Ed.; Springer: Basel, Switzerland, 2012; Volume 101, pp. 133-164.

137. Hussain, M.M.; Wang, J.; Bibi, I.; Shahid, M.; Niazi, N.K.; Iqbal, J.; Mian, I.A.; Shaheen, S.M.; Bashir, S.; Shah, N.S.; et al. Arsenic Speciation and Biotransformation pathways in the Aquatic Ecosystem: The Significance of Algae. J. Hazard. Mater. 2021, 403, 124027. [CrossRef]

138. Cheng, H.; Hu, Y.; Luo, J.; Xu, B.; Zhao, J. Geochemical Processes Controlling Fate and Transport of Arsenic in Acid Mine Drainage (AMD) and Natural systems. J. Hazard. Mater. 2009, 165, 13-26. [CrossRef]

139. Garelick, H.; Jones, H.; Dybowska, A.; Valsami-Jones, E. Arsenic pollution sources. In Reviews of Environmental Contamination and Toxicology (Continuation of Residue Reviews); Springer: New York, NY, USA, 2009; Volume 197, pp. 17-60. ISBN 9780387792835.

140. Rahman, M.A.; Hasegawa, H. Aquatic Arsenic: Phytoremediation Using Floating Macrophytes. Chemosphere 2011, 83, $633-646$. [CrossRef]

141. Ventura-Lima, J.; Bogo, M.R.; Monserrat, J.M. Arsenic Toxicity in Mammals and Aquatic Animals: A Comparative Biochemical Approach. Ecotoxicol. Environ. Saf. 2011, 74, 211-218. [CrossRef]

142. Khang, H.V.; Hatayama, M.; Inoue, C. Arsenic Accumulation by Aquatic Macrophyte coontail (Ceratophyllum demersum L.) Exposed to Arsenite, and the Effect of Iron on the Uptake of Arsenite and Arsenate. Environ. Exp. Bot. 2012, 83, 47-52. [CrossRef]

143. Sharma, V.K.; Sohn, M. Aquatic arsenic: Toxicity, Speciation, Transformations, and Remediation. Environ. Int. 2009, 35, 743-759. [CrossRef]

144. Maher, W.A. Arsenic in Marine Organisms. Biol. Trace Elem. Res. 1984, 6, 159-164. [CrossRef]

145. Sarkar, B. Heavy Metals in the Environment; Sarkar, B., Ed.; Marcel Dekker, Inc.: New York, NY, USA, 2002; ISBN 0-8247-0630-7.

146. Irvine, L.; Boyer, I.J.; DeSesso, J.M. Monomethylarsonic Acid and Dimethylarsinic Acid: Developmental Toxicity Studies With Risk Assessment. Birth Defects Res. B. Dev. Reprod. Toxicol. 2006, 77, 53-68. [CrossRef]

147. Falinski, K.A.; Yost, R.S.; Sampaga, E.; Peard, J. Arsenic Accumulation by Edible Aquatic Macrophytes. Ecotoxicol. Environ. Saf. 2014, 99, 74-81. [CrossRef]

148. Canivet, V.; Chambon, P.; Gibert, J. Toxicity and Bioaccumulation of Arsenic and Chromium in Epigean and Hypogean Freshwater Macroinvertebrates. Arch. Environ. Contam. Toxicol. 2001, 40, 345-354. [CrossRef]

149. Chi, S.; Hu, J.; Zheng, J.; Dong, F. Study on the Effects of Arsenic Pollution on the Communities of Macroinvertebrate in Xieshui River. Acta Ecol. Sin. 2017, 37, 1-9. [CrossRef]

150. Das, P.K.; Das, B.P.; Dash, P. Hexavalent Chromium Induced Toxicity and its Remediation Using Macrophytes. Pollut. Res. 2017, $36,92-98$. 
151. Das, P.K.; Das, B.P.; Dash, P. Chromite Mining Pollution, Environmental Impact, Toxicity and Phytoremediation: A Review. Environ. Chem. Lett. 2021, 19, 1369-1381. [CrossRef]

152. Malaj, E.; Grote, M.; Schäfer, R.B.; Brack, W.; von der Ohe, P.C. Physiological Sensitivity of Freshwater Macroinvertebrates to Heavy Metals. Environ. Toxicol. Chem. 2012, 31, 1754-1764. [CrossRef]

153. Erasmus, J.H.; Malherbe, W.; Zimmermann, S.; Lorenz, A.W.; Nachev, M.; Wepener, V.; Sures, B.; Smit, N.J. Metal Accumulation in Riverine Macroinvertebrates from a Platinum Mining Region. Sci. Total Environ. 2020, 703, 134738. [CrossRef]

154. Mufarrege, M.M.; Hadad, H.R.; Maine, M.A. Response of Pistia stratiotes to Heavy Metals (Cr, Ni, and Zn) and Phosphorous. Arch. Environ. Contam. Toxicol. 2010, 58, 53-61. [CrossRef]

155. Bai, L.; Liu, X.L.; Hu, J.; Li, J.; Wang, Z.L.; Han, G.; Li, S.L.; Liu, C.Q. Heavy Metal Accumulation in Common Aquatic Plants in Rivers and Lakes in the Taihu Basin. Int. J. Environ. Res. Public Health 2018, 15, 2857. [CrossRef]

156. Prajapati, S.K.; Meravi, N.; Singh, S. Phytoremediation of Chromium and Cobalt using Pistia stratiotes: A Sustainable Approach. Proc. Int. Acad. Ecol. Environ. Sci. 2012, 2, 136-138.

157. Clements, W.H.; Cadmus, P.; Brinkman, S.F. Responses of Aquatic Insects to Cu and Zn in Stream Microcosms: Understanding Differences Between Single Species Tests and field Responses. Environ. Sci. Technol. 2013, 47, 7506-7513. [CrossRef]

158. Mebane, C.A.; Schmidt, T.S.; Miller, J.L.; Balistrieri, L.S. Bioaccumulation and Toxicity of Cadmium, Copper, Nickel, and Zinc and Their Mixtures to Aquatic Insect Communities. Environ. Toxicol. Chem. 2020, 39, 812-833. [CrossRef]

159. Joachim, S.; Roussel, H.; Bonzom, J.M.; Thybaud, E.; Mebane, C.A.; Van den Brink, P.; Gauthier, L. A Long-term Copper Exposure in a Freshwater Ecosystem Using Lotic Mesocosms: Invertebrate Community Responses. Environ. Toxicol. Chem. 2017, 36, 2698-2714. [CrossRef]

160. Basile, A.; Sorbo, S.; Conte, B.; Castaldo Cobianchi, R.; Trinchella, F.; Capasso, C.; Carginale, V. Toxicity, Accumulation, and Removal of Heavy Metals by Three Aquatic Macrophytes. Int. J. Phytoremediation 2012, 14, 374-387. [CrossRef]

161. Mal, T.K.; Adorjan, P.; Corbett, A.L. Effect of Copper on Growth of an Aquatic Macrophyte, Elodea canadensis. Environ. Pollut. 2002, 120, 307-311. [CrossRef]

162. Singh, H.; Kumar, D.; Soni, V. Copper and Mercury Induced Oxidative Stresses and Antioxidant Responses of Spirodela polyrhiza (L.) Schleid. Biochem. Biophys. Rep. 2020, 23, 100781. [CrossRef]

163. Rama Devi, S.; Prasad, M.N. Copper Toxicity in Ceratophyllum demersum L. (Coontail), a Free Floating Macrophyte: Response of Antioxidant Enzymes and Antioxidants. Plant Sci. 1998, 138, 157-165. [CrossRef]

164. Amirbahman, A.; Massey, D.I.; Lotufo, G.; Steenhaut, N.; Brown, L.E.; Biedenbach, J.M.; Magar, V.S. Assessment of Mercury Bioavailability to Benthic Macroinvertebrates Using Diffusive Gradients in Thin Films (DGT). Environ. Sci. Process. Impacts 2013, 15, 2104-2114. [CrossRef]

165. Chattopadhyay, S. Grain incidents and other mercury tragedies: Forms, fate, and effects. In Encyclopedia of Toxicology, 2nd ed.; Elsevier: Amsterdam, The Netherlands, 2005; pp. 464-469. ISBN 9780123694003.

166. Regier, N.; Larras, F.; Bravo, A.G.; Ungureanu, V.G.; Amouroux, D.; Cosio, C. Mercury Bioaccumulation in the Aquatic Plant Elodea nuttallii in the Field and in Microcosm: Accumulation in Shoots from the Water might Involve Copper Transporters. Chemosphere 2013, 90, 595-602. [CrossRef]

167. Bittencourt, L.O.; Nascimento, P.C.; Aragão, W.A.B.; Puty, B.; Lima, R.R. Methylmercury, oxidative stress, and neurodegeneration. In Toxicology; Elsevier: Amsterdam, The Netherlands, 2021; pp. 137-144.

168. Roxanna Razavi, N.; Cushman, S.F.; Halfman, J.D.; Massey, T.; Beutner, R.; Cleckner, L.B. Mercury Bioaccumulation in Stream Food Webs of the Finger Lakes in Central New York State, USA. Ecotoxicol. Environ. Saf. 2019, 172, 265-272. [CrossRef]

169. Verhaert, V.; Teuchies, J.; Vlok, W.; Wepener, V.; Addo-Bediako, A.; Jooste, A.; Blust, R.; Bervoets, L. Bioaccumulation and Trophic Transfer of Total Mercury in the Subtropical Olifants River Basin, South Africa. Chemosphere 2019, 216, 832-843. [CrossRef]

170. Riva-Murray, K.; Bradley, P.M.; Brigham, M.E. Methylmercury-Total Mercury Ratios in Predator and Primary Consumer Insects from Adirondack Streams (New York, USA). Ecotoxicology 2020, 29, 1644-1658. [CrossRef]

171. Mhin, B.J.; Lee, S.; Cho, S.J.; Lee, K.; Kim, K.S. Zn(H2O)2+6 is Very Stable Among Aqua-Zn(II) ions. Chem. Phys. Lett. 1992, 197, 77-80. [CrossRef]

172. Iwasaki, Y.; Kagaya, T.; Miyamoto, K.; Matsuda, H. Responses of Riverine Macroinvertebrates to Zinc in Natural Streams: Implications for the Japanese Water Quality Standard. Water Air Soil Pollut. 2012, 223, 145-158. [CrossRef]

173. Lidman, J.; Jonsson, M.; Berglund, Å.M.M. The Effect of Lead (Pb) and Zinc (Zn) Contamination on Aquatic Insect Community Composition and Metamorphosis. Sci. Total Environ. 2020, 734, 139406. [CrossRef]

174. Ziglio, G.; Siligardi, M.; Flaim, G. Biological Monitoring of Rivers: Applications and Perspectives; Quevauviller, P., Ed.; John Wiley \& Sons Ltd: Chichester, UK, 2006; ISBN 9780470863763.

175. Driessen, P.F.M.; Verdonschot, J.M.C.; Mosterdijk, H.G.; Schot, J.A. The 5-S-model, an integrated approach for stream rehabilitation. In Proceedings of the International Conference arranged by the European Centre for River Restoration; Institute for Forestry and Nature Research: Northern Zealand, Denmark, 1998; p. 294.

176. De Cooman, W.; Florus, M.; Vangheluwe, M.; Janssen, C.; Heylen, S.; De Pauw, N.; Rillaerts, E.; Meire, P.; Verheyen, R. Sediment characterisation of rivers in flanders. The triad approach BT-characterisation and treatment of sediments. In Characterisation and Treatment of Sediments; De Schutter, G., Ed.; PIH Antwerpen: Antwerpen, Belgium, 1999; pp. 351-363.

177. De Pauw, N.; Heylen, S. Biotic Index for Sediment Quality Assessment of Watercourses in Flanders, Belgium. Aquat. Ecol. 2001, 35, 121-133. [CrossRef] 
178. Bidwell, J.R. Physical and chemical monitoring of wetland water. In Wetland Techniques: Volume 1: Foundations; Springer: Dordrecht, The Netherlands, 2013; pp. 325-353. ISBN 9789400768604.

179. Meck, M.L.; Masamba, W.R.L.; Atlhopheng, J.; Ringrose, S. Natural Attenuation of Mining Pollutants in the Transboundary Save River. Phys. Chem. Earth Parts A/B/C 2011, 36, 836-841. [CrossRef]

180. Biney, C.; Amuzu, A.T.; Calamari, D.; Kaba, N.; Mbome, I.L.; Naeve, H.; Ochumba, P.B.O.; Osibanjo, O.; Radegonde, V.; Saad, M.A.H. Review of Heavy Metals in the African Aquatic Environment. Ecotoxicol. Environ. Saf. 1994, 28, 134-159. [CrossRef]

181. Sikamo, J. Copper Mining in Zambia-History and Future. J. South. Afr. Inst. Min. Metall. 2016, 116, 491-496. [CrossRef]

182. Nejeschlebová, L.; Sracek, O.; Mihaljevič, M.; Ettler, V.; Kříbek, B.; Knésl, I.; Vaněk, A.; Penížek, V.; Dolníček, Z.; Mapani, B. Geochemistry and Potential Environmental Impact of the Mine Tailings at Rosh Pinah, Southern Namibia. J. Afr. Earth Sci. 2015, 105, 17-28. [CrossRef]

183. Izegaegbe, J.I.; Vivier, L.; Mzimela, H.M. Trace Metal Contamination in Sediment in the Mhlathuze Estuary, Northern KwaZuluNatal, South Africa: Effects on the Macrobenthic Community. Environ. Monit. Assess. 2020, 192, 401. [CrossRef]

184. Zhou, Q.; Zhang, J.; Fu, J.; Shi, J.; Jiang, G. Biomonitoring: An Appealing Tool for Assessment of Metal Pollution in the Aquatic Ecosystem. Anal. Chim. Acta 2008, 606, 135-150. [CrossRef]

185. Gerhardt, A. Bioindicator Species and Their Use in Biomonitoring. Encycl. life Support Syst. Environ. Monit. 2002, I, 1-10.

186. Stankovic, S.; Kalaba, P.; Stankovic, A.R. Biota as Toxic Metal Indicators. Environ. Chem. Lett. 2014, 12, 63-84. [CrossRef]

187. Herman, M.R.; Nejadhashemi, A.P. A Review of Macroinvertebrate- and Fish-based Stream Health Indices. Ecohydrol. Hydrobiol. 2015, 15, 53-67. [CrossRef]

188. Graham, P.M.; Dickens, C.W.; Taylor, R.J. miniSASS-A Novel Technique for Community Participation in River Health Monitoring and Management. Afr. J. Aquat. Sci. 2004, 29, 25-35. [CrossRef]

189. Dickens, C.W.S.; Graham, P.M. The South African Scoring System (SASS) Version 5 Rapid Bioassessment Method for Rivers. Afr. J. Aquat. Sci. 2002, 27, 1-10. [CrossRef]

190. Dallas, H.F.; Lowe, S.; Kennedy, M.P.; Saili, K.; Murphy, K.J. Zambian Invertebrate Scoring System (ZISS): A Macroinvertebratebased Biotic Index for Rapid Bioassessment of Southern Tropical African River Systems. Afr. J. Aquat. Sci. 2018, 43, 325-344. [CrossRef]

191. Agboola, O.A.; Downs, C.T.; O’Brien, G. Macroinvertebrates as Indicators of Ecological Conditions in the Rivers of KwaZulu-Natal, South Africa. Ecol. Indic. 2019, 106, 105465. [CrossRef]

192. Ollis, D.J.; Dallas, H.F.; Esler, K.J.; Boucher, C. Bioassessment of the Ecological Integrity of River Ecosystems using Aquatic Macroinvertebrates: An Overview with a Focus on South Africa. Afr. J. Aquat. Sci. 2006, 31, 205-227. [CrossRef]

193. Addo-Bediako, A.; Malakane, K. Preliminary Assessment of Chemical Elements in Sediments and Larvae of Gomphidae (Odonata) from the Blyde River of the Olifants River System, South Africa. Int. J. Environ. Res. Public Health 2020, 17, 8135. [CrossRef]

194. López-López, E.; Sedeño-Díaz, J.E. Biological Indicators of Water Quality: The role of Fish and Macroinvertebrates as Indicators of Water Quality. In Environmental Indicators; Springer: Dordrecht, The Netherlands, 2015; pp. 643-661. ISBN 9789401794992.

195. Utete, B.; Fregene, B.T. Heavy Metal Concentrations in Surface Water, Sediments and Fish and their Potential Toxicity in Highly Degraded Multipurpose Peri-Urban Eleyele Lake, Ibadan City, Oyo State, South-Western Nigeria. Cogent Environ. Sci. 2020, 6, 1785137. [CrossRef]

196. Zeitoun, M.M.; Mehana, E.S.E. Impact of Water Pollution with Heavy Metals on Fish Health: Overview and Updates. Glob. Vet. 2014, 12, 219-231. [CrossRef]

197. Kaile, B.; Nyirenda, J. Assessing the Bioaccumulative Impact of Four Heavy Metals on the Endocrine System of Tilapia rendalli Fish Species in the Kafue River. Annu. Res. Rev. Biol. 2016, 9, 1-23. [CrossRef]

198. Mbewe, G.; Mutondo, M.; Maseka, K.; Sichilongo, K. Assessment of Heavy-Metal Pollution in Sediments and Tilapia Fish Species in Kafue River of Zambia. Arch. Environ. Contam. Toxicol. 2016, 71, 383-393. [CrossRef]

199. Schmitt, C.J.; Brumbaugh, W.G.; Linder, G.L.; Hinck, J.E. A Screening-Level Assessment of Lead, Cadmium, and Zinc in Fish and Crayfish from Northeastern Oklahoma, USA. Environ. Geochem. Health 2006, 28, 445-471. [CrossRef]

200. Alam, L.; Mokhtar, M.B.; Alam, M.M.; Bari, M.A.; Kathijotes, N.; Ta, G.C.; Ern, L.K. Assessment of Environmental and Human Health Risk for Contamination of Heavy Metal in Tilapia Fish Collected from Langat Basin, Malaysia. Asian J. Water Environ. Pollut. 2015, 12, 21-30.

201. Lear, G.; Niyogi, D.; Harding, J.; Dong, Y.; Lewis, G. Biofilm Bacterial Community Structure in Streams Affected by Acid Mine Drainage. Appl. Environ. Microbiol. 2009, 75, 3455-3460. [CrossRef]

202. Staebe, K.; Botes, M.; Madlala, T.; Oberholster, P.J.; Cloete, T.E. Microbial Community Diversity as a Potential Bioindicator of AMD and Steel Plant Effluent in a Channelled Valley Bottom Wetland. Water Air Soil Pollut. 2018, 229. [CrossRef]

203. Bellinger, E.G.; Sigee, D.C. Freshwater Algae: Identification and Use as Bioindicators, 1st ed.; John Wiley \& Sons Ltd: Chichester, UK, 2010; ISBN 9780470058145.

204. Mangadze, T.; Bere, T.; Mwedzi, T. Choice of Biota in Stream Assessment and Monitoring Programs in Tropical Streams: A Comparison of Datoms, Macroinvertebrates and Fish. Ecol. Indic. 2016, 63, 128-143. [CrossRef]

205. Oberholster, P.J.; Genthe, B.; Hobbs, P.; Cheng, P.H.; de Klerk, A.R.; Botha, A.M. An Ecotoxicological Screening Tool to Prioritise Acid Mine Drainage Impacted Streams for Future Restoration. Environ. Pollut. 2013, 176, 244-253. [CrossRef] 
206. Tolotti, R.; Consani, S.; Carbone, C.; Vagge, G.; Capello, M.; Cutroneo, L. Benthic Diatom Community Cesponse to Metal Contamination from an Abandoned Cu Mine: Case Study of the Gromolo Torrent (Italy). J. Environ. Sci. 2019, 75, $233-246$. [CrossRef]

207. Ladislas, S.; El-Mufleh, A.; Gérente, C.; Chazarenc, F.; Andrès, Y.; Béchet, B. Potential of Aquatic Macrophytes as Bioindicators of Heavy Metal Pollution in Urban Stormwater Runoff. Water Air Soil Pollut. 2012, 223, 877-888. [CrossRef]

208. Oberholster, P.J.; Madlala, T.E.; Oberholster, P.F.; Kanyerere, T.; Botha, A.-M. Using an ecotoxicological screening tool in the post mining landscape to identify acid mine drainage impacted streams as candidates for passive treatment technology. In Acid Mine Drainage: Chemistry, Effects and Treatment; Nova Science Publishers, Inc.: New York, NY, USA, 2018; pp. 65-92. ISBN 9781536142235.

209. Rai, P.K. Heavy Metal Pollution in Aquatic Ecosystems and its Phytoremediation Using Wetland Plants: An Ecosustainable Approach. Int. J. Phytoremediation 2008, 10, 133-160. [CrossRef]

210. Gupta, D.K.; Chatterjee, S.; Walther, C. Lead in Plants and the Environment; Gupta, D.K., Chatterjee, S., Walther, C., Eds.; Radionuclides and Heavy Metals in the Environment; Springer International Publishing: Cham, Switzerland, 2020; Volume 5, ISBN 978-3-030-21637-5.

211. da Silva, F.L.; Stefani, M.S.; Smith, W.; Schiavone, D.C.; da Cunha-Santino, M.B.; Bianchini, I., Jr. An Applied Ecological Approach for the Assessment of Anthropogenic Disturbances in Urban Wetlands and the Contributor River. Ecol. Complex. 2020, $43,100852$. [CrossRef]

212. Chen, S.; Chen, B.; Fath, B.D. Ecological Risk Assessment on the System Scale: A Review of State-of-the-Art Models and Future Perspectives. Ecol. Modell. 2013, 250, 25-33. [CrossRef]

213. Péru, N.; Dolédec, S. From Compositional to Functional Biodiversity Metrics in Bioassessment: A case Study Using Stream Macroinvertebrate Communities. Ecol. Indic. 2010, 10, 1025-1036. [CrossRef]

214. Moog, O.; Schmutz, S.; Schwarzinger, I. Biomonitoring and bioassessment. In Riverine Ecosystem Management: Science for Governing Towards a Sustainable Future; Schmutz, S., Sendzimir, J., Eds.; Springer International Publishing: Cham, Switzerland, 2018; pp. 371-390. ISBN 978-3-319-73250-3.

215. Reynoldson, T.B.; Norris, R.H.; Resh, V.H.; Day, K.E.; Rosenberg, D.M. The Reference Condition: A Comparison of Multimetric and Multivariate Approaches to Assess Water-Quality Impairment Using Benthic Macroinvertebrates. J. N. Am. Benthol. Soc. 1997, 16, 833-852. [CrossRef]

216. Borisko, J.P.; Kilgour, B.W.; Stanfield, L.W.; Jones, F.C. An Evaluation of Rapid Bioassessment Protocols for Stream Benthic Invertebrates in Southern Ontario, Canada. Water Qual. Res. J. Can. 2007, 42, 184-193. [CrossRef]

217. Karr, J.R. Biological Integrity: A Long-Neglected Aspect of Water Resource Management. Ecol. Appl. 1991, 1, 66-84. [CrossRef]

218. Steyn, M.; Oberholster, P.J.; Botha, A.M.; Genthe, B.; van den Heever-Kriek, P.E.; Weyers, C. Treated Acid Mine Drainage and Stream Recovery: Downstream Impacts on Benthic Macroinvertebrate Communities in Relation to Multispecies Toxicity Bioassays. J. Environ. Manag. 2019, 235, 377-388. [CrossRef]

219. Chutter, F.M. Research on the Rapid Biological Assessment of Water Quality Impacts in Streams and Rivers; Pretoria, South Africa, 1998. Available online: http:/ / www.wrc.org.za/wp-content/uploads/mdocs/422-1-98.pdf (accessed on 29 November 2021).

220. Dallas, H.F. Wetland Monitoring Using Aquatic Macroinvertebrates: Technical Report 5/2009 Prepared for the Biokavango Project. Open J. Ecol. 2009, 11, 4.

221. Palmer, R.; Taylor, E. The Namibian Scoring System (NASS) Version 2 Rapid Bioassessment Method for Rivers. Afr. J. Aquat. Sci. 2004, 29, 229-234. [CrossRef]

222. Kaaya, L.; Day, J.; Dallas, H. Tanzania River Scoring System (TARISS): A Macroinvertebrate-based Biotic Index for Rapid Bioassessment of Rivers. Afr. J. Aquat. Sci. 2015, 40, 109-117. [CrossRef]

223. Kleynhans, C.J. The Development of a Fish Index to Assess the Biological Integrity of South African Rivers. Water SA 1999, 25, 265-278.

224. Karr, J.R. Assessment of Biotic Integrity Using Fish Communities. Fisheries 1981, 6, 21-27. [CrossRef]

225. Kleynhans, C.J.; Thirion, C.; Moolman, J. A Level I River Ecoregion Classification System for South Africa, Lesotho and Swaziland. Report No. N/0000/00/REQ0104; Department of Water Affairs and Forestry Resource Quality Services: Pretoria, South Africa, 2005.

226. Kennedy, M.P.; Lang, P.; Tapia, G.J.; Varandas, M.S.; Bruce, A.; Lowe, S.; Dallas, H.; Davidson, T.A.; Sichingabula, H.; Briggs, J.; et al. The Zambian Macrophyte Trophic Ranking Scheme, ZMTR: A New Biomonitoring Protocol to Assess the Trophic Status of Tropical Southern African Rivers. Aquat. Bot. 2016, 131, 15-27. [CrossRef]

227. Harding, W.R.; Taylor, J.C. The South African Diatom Index (SADI): A Preliminary Index for Indicating Water Quality in Rivers and Streams in Southern Africa: Report to the Water Research Commission; Water Research Commission: Pretoria, South Africa, 2011; ISBN 1431201723.

228. Harding, W.R.; Taylor, J.C. Diatoms as Indicators of Historical Water Quality: A Comparison of Samples taken in the Wemmershoek Catchment (Western Province, South Africa) in 1960 and 2008. Water SA 2014, 40, 601. [CrossRef]

229. USEPA Ecological Risk Assessment. Available online: https://19january2017snapshot.epa.gov/risk/ecological-risk-assessment_ .html (accessed on 21 January 2021).

230. Husain, T.; Sadiq, R.; Mukhtasor; Khan, A.A.; Khan, N.Y.; Munawar, M.; Price, A.R.G. Framework for ecological risk assessment: Deterministic and probabilistic analyses. In The Gulf Ecosystem Health and Sustainability; Khan, N.Y., Price, A.R.G., Eds.; Michigan State University Press: East Lansing, MI, USA, 2014; pp. 377-396. ISBN 9780992100711. 
231. Harwell, M.A.; Gentile, J.H.; Johnson, C.B.; Garshelis, D.L.; Parker, K.R. A quantitative ecological risk assessment of the toxicological risks from exxon valdez subsurface oil residues to sea otters at Northern Knight Island, Prince William Sound, Alaska. Hum. Ecol. Risk Assess. 2010, 16, 727-761. [CrossRef]

232. Sharifi, Z.; Hossaini, S.M.T.; Renella, G. Risk Assessment for Sediment and Stream Water Polluted by Heavy Metals Released by a Municipal Solid Waste Composting Plant. J. Geochem. Explor. 2016, 169, 202-210. [CrossRef]

233. Zhao, Z.; Zhang, T. Ecological Risk Assessment of China's Freshwater Ecosystems Applying the Relative Risk Model: Toward an Ecosystem-Based Water Management in China. Hum. Ecol. Risk Assess. 2013. [CrossRef]

234. El Azhari, A.; Rhoujjati, A.; El Hachimi, M.L.; Ambrosi, J. Pollution and Ecological Risk Assessment of Heavy Metals in the Soil-Plant System and the Sediment-Water Column around a Former Pb/Zn-Mining Area in NE Morocco. Ecotoxicol. Environ. Saf. 2017, 144, 464-474. [CrossRef]

235. O'Brien, G.; Wepener, V. Regional-Scale Risk Assessment Methodology Using the Relative Risk Model (RRM) for Surface Freshwater Aquatic Ecosystems in South Africa. Water SA 2012, 38. [CrossRef]

236. Mandeng, E.P.B.; Bidjeck, L.M.B.; Bessa, A.Z.E.; Ntomb, Y.D.; Wadjou, J.W.; Doumo, E.P.E.; Dieudonné, L.B. Contamination and Risk Assessment of Heavy Metals, and Uranium of Sediments in Two Watersheds in Abiete-Toko Gold District, Southern Cameroon. Heliyon 2019, 5, e02591. [CrossRef]

237. Zinabu, E.; Kelderman, P.; van der Kwast, J.; Irvine, K. Impacts and Policy Implications of Metals Effluent Discharge into Rivers within Industrial Zones: A Sub-Saharan Perspective from Ethiopia. Environ. Manag. 2018, 61, 700-715. [CrossRef] [PubMed]

238. Nkansah, M.A.; Darko, G.; Dodd, M.; Opoku, F.; Bentum Essuman, T.; Antwi-Boasiako, J.; Fantke, P. Assessment of Pollution Levels, Potential Ecological Risk and Human Health Risk of Heavy Metals/Metalloids in Dust Around Fuel Filling Stations from the Kumasi Metropolis, Ghana. Cogent Environ. Sci. 2017, 3, 1412153. [CrossRef]

239. Vetrimurugan, E.; Shruti, V.C.; Jonathan, M.P.; Roy, P.D.; Sarkar, S.K.; Rawlins, B.K.; Villegas, L.E.C. Comprehensive Study on Metal Contents and Their Ecological Risks in Beach Sediments of KwaZulu-Natal Province, South Africa. Mar. Pollut. Bull. 2019, 149, 110555. [CrossRef] [PubMed]

240. Zhao, H.; Xia, B.; Fan, C.; Zhao, P.; Shen, S. Human Health Risk from Soil Heavy Metal Contamination Under Different Land Uses Near Dabaoshan Mine, Southern China. Sci. Total Environ. 2012, 417-418, 45-54. [CrossRef]

241. Kumari, P.; Chowdhury, A.; Maiti, S.K. Assessment of Heavy Metal in the Water, Sediment, and Two Edible Fish Species of Jamshedpur Urban Agglomeration, India with Special Emphasis on Human Health Risk. Hum. Ecol. Risk Assess. Int. J. 2018, 24, 1477-1500. [CrossRef]

242. Teta, C.; Ncube, M.; Naik, Y. Heavy Metal Contamination of Water and Fish in Peri-Urban Dams Around Bulawayo, Zimbabwe. Afr. J. Aquat. Sci. 2017, 42, 351-358. [CrossRef]

243. Häder, D.P.; Banaszak, A.T.; Villafañe, V.E.; Narvarte, M.A.; González, R.A.; Helbling, E.W. Anthropogenic Pollution of Aquatic Ecosystems: Emerging Problems with Global Implications. Sci. Total Environ. 2020, 713, 136586. [CrossRef]

244. Yilmaz, A.B. Heavy metal pollution in aquatic environments. In Impact, Monitoring and Management of Environmental Pollution; Nova Science Publishers, Inc.: Hauppauge, NY, USA, 2011; pp. 193-221. ISBN 9781608764877.

245. Ali, H.; Khan, E.; Ilahi, I. Environmental Chemistry and Ecotoxicology of Hazardous Heavy Metals: Environmental Persistence, Toxicity, and Bioaccumulation. J. Chem. 2019, 2019, 1-14. [CrossRef]

246. Roșu, C.; Roba, C.; Voica, C.; Bindiu, S. Chemical Characterisation of Acid Mine Drainage and its Impact on Surface Water Quality in the Former Mining Area of Valea Vinului (Bistrița County - Romania). Stud. Univ. Babeș-Bolyai Ambient. 2018, 63, 89-100. [CrossRef]

247. Kumar, V.; Parihar, R.D.; Sharma, A.; Bakshi, P.; Singh Sidhu, G.P.; Bali, A.S.; Karaouzas, I.; Bhardwaj, R.; Thukral, A.K.; Gyasi-Agyei, Y.; et al. Global Evaluation of Heavy Metal Content in Surface Water Bodies: A Meta-analysis Using Heavy Metal Pollution Indices and Multivariate Statistical Analyses. Chemosphere 2019, 236, 124364. [CrossRef] [PubMed]

248. Amoatey, P.; Baawain, M.S. Effects of Pollution on Freshwater Aquatic Organisms. Water Environ. Res. Res. Publ. Water Environ. Fed. 2019, 91, 1272-1287. [CrossRef]

249. Li, H.; Yang, J.; Ye, B.; Jiang, D. Pollution Characteristics and Ecological Risk Assessment of 11 Unheeded Metals in Sediments of the Chinese Xiangjiang River. Environ. Geochem. Health 2019, 41, 1459-1472. [CrossRef] [PubMed]

250. Siddiqui, E.; Pandey, J. Assessment of Heavy Metal Pollution in Water and Surface Sediment and Evaluation of Ecological Risks Associated with Sediment Contamination in the Ganga River: A Basin-Scale Study. Environ. Sci. Pollut. Res. 2019, 26, 10926-10940. [CrossRef]

251. Usman, Q.A.; Muhammad, S.; Ali, W.; Yousaf, S.; Jadoon, I.A.K. Spatial Distribution and Provenance of Heavy Metal Contamination in the Sediments of the Indus River and its Tributaries, North Pakistan: Evaluation of Pollution and Potential Risks. Environ. Technol. Innov. 2021, 21, 101184. [CrossRef]

252. Ippolito, A.; Sala, S.; Faber, J.H.; Vighi, M. Ecological Vulnerability Analysis: A River Basin Case Study. Sci. Total Environ. 2010, 408, 3880-3890. [CrossRef] [PubMed]

253. Cura, J.J.; Heiger-Bernays, W.; Bridges, T.S.; Moore, D.W. Ecological and Human Health Risk Assessment Guidance for Aquatic Environments. Technical Report DOER-4; U.S. Army Engineer Research and Development Center: Washington, DC, USA, 1999.

254. Ingersoll, C.G.; MacDonald, D.D. A Guidance Manual to Support the Assessment of Contaminated Sediments in Freshwater EcosystemsVolume III-Interpretation of the Results of Sediment Quality Investgations; United States Environmental Protection Agency: Chicago, IL, USA, 2002. 
255. Suter, G.W., II; Barnthouse, L.W.; Bartell, S.M.; Cormier, S.M.; Mackay, D.; Mackay, N.; Norton, S.B. Ecological Risk Assessment, 2nd ed.; Suter, G.W., II, Eds.; CRC Press, Taylor \& Francis Group, LLC: London, UK, 2007; ISBN 1-56670-634-3.

256. Warren-Hicks, W.J.; Parkhurst, B.R.; Butcher, J.B. Methodology for aquatic ecological risk assessment. In Species Sensitivity Distributions in Ecotoxicology; CRC Press LLC: Boca Raton, FL, USA, 2002; pp. 345-382. ISBN 9781420032314.

257. Bedford, T.; Cooke, R.M. Probabilistic Risk Analysis: Foundations and Methods; Cambridge University Press: Cambridge, UK, 2001.

258. US EPA. Guidelines for Ecological Risk Assessment; USEPA: Washington, DC, USA, 1998.

259. Packhurst, B. Risk Assessment Methods; Water Environment Federation: Washington DC, USA, 1995.

260. Kowalska, J.B.; Mazurek, R.; Gasiorek, M.; Zaleski, T. Pollution Indices as Useful Tools for the Comprehensive Evaluation of the Degree of Soil Contamination: A Review. Environ. Geochem. Health 2018, 40, 2395-2420. [CrossRef]

261. Hakanson, L. An Ecological Risk Index for Aquatic Pollution Control: A Sedimentological Approach. Water Res. 1980, 14, 975-1001. [CrossRef]

262. Vaezi, A.; Karbassi, A.; Fakhraee, M.; Samani, A.V.; Heidari, M. Assessment of Sources and Concentration of Metal Contaminants in Marine Sediments of Musa Estuary, Persian Gulf. J. Environ. Stud. 2014, 40, 345-360.

263. Nkinda, M.S.; Rwiza, M.J.; Ijumba, J.N.; Njau, K.N. Quantitative Assessment of Metal Contamination and Associated Pollution Risk in Sediments from the Mara River in Tanzania. Environ. Monit. Assess. 2020, 192, 721. [CrossRef]

264. Kilunga, P.I.; Sivalingam, P.; Laffite, A.; Grandjean, D.; Mulaji, C.K.; de Alencastro, L.F.; Mpiana, P.T.; Poté, J. Accumulation of Toxic Metals and Organic Micro-pollutants in Sediments from Tropical Urban Rivers, Kinshasa, Democratic Republic of the Congo. Chemosphere 2017, 179, 37-48. [CrossRef]

265. Jadoon, W.A.; Khpalwak, W.; Chidya, R.C.G.; Abdel-Dayem, S.M.M.A.; Takeda, K.; Makhdoom, M.A.; Sakugawa, H. Evaluation of Levels, Sources and Health Hazards of Road-Dust Associated Toxic Metals in Jalalabad and Kabul Cities, Afghanistan. Arch. Environ. Contam. Toxicol. 2018, 74, 32-45. [CrossRef]

266. Shu, W.; Wang, P.; Zhao, J.; Yu, X.; Xu, Q. Characteristics, Sources and Risk Assessment of Heavy Metals in the Ganjiang River Basin, China. Polish J. Environ. Stud. 2020, 29, 1849-1868. [CrossRef]

267. Isimekhai, K.A.; Garelick, H.; Watt, J.; Purchase, D. Heavy Metals Distribution and Risk Assessment in Soil from an Informal E-waste Recycling Site in Lagos State, Nigeria. Environ. Sci. Pollut. Res. 2017, 24, 17206-17219. [CrossRef]

268. Chapman, P.M. Do Not Disregard the Benthos in Sediment Quality Assessments! Mar. Pollut. Bull. 2007, 54, 633-635. [CrossRef] [PubMed]

269. Chapman, P.M.; Anderson, J. A Decision-Making Framework for Sediment Contamination. Integr. Environ. Assess. Manag. 2005, 1, 163. [CrossRef]

270. Grapentine, L.; Anderson, J.; Boyd, D.; Burton, G.A.; DeBarros, C.; Johnson, G.; Marvin, C.; Milani, D.; Painter, S.; Pascoe, T.; et al. A Decision Making Framework for Sediment Assessment Developed for the Great Lakes. Hum. Ecol. Risk Assess. Int. J. 2002, 8, 1641-1655. [CrossRef]

271. Chapman, P.M.; Hollert, H. Should the Sediment Quality Triad Become a Tetrad, a Pentad, or Possibly even a Hexad? J. Soils Sediments 2006, 6, 4-8. [CrossRef]

272. Varol, M. Environmental, Ecological and Health Risks of Trace Metals in Sediments of a Large Reservoir on the Euphrates River (Turkey). Environ. Res. 2020, 187, 109664. [CrossRef]

273. Pandey, B.; Agrawal, M.; Singh, S. Ecological Risk Assessment of Soil Contamination by Trace Elements Around Coal Mining Area. J. Soils Sediments 2016, 16, 159-168. [CrossRef]

274. Mugoša, B.; Đurović, D.; Nedović-Vuković, M.; Barjaktarović-Labović, S.; Vrvić, M. Assessment of Ecological Risk of Heavy Metal Contamination in Coastal Municipalities of Montenegro. Int. J. Environ. Res. Public Health 2016, 13, 393. [CrossRef]

275. Sadeghi Poor Sheijany, M.; Shariati, F.; Yaghmaeian Mahabadi, N.; Karimzadegan, H. Evaluation of Heavy Metal Contamination and Ecological Risk of Soil Adjacent to Saravan Municipal Solid Waste Disposal Site, Rasht, Iran. Environ. Monit. Assess. 2020, 192, 757. [CrossRef] [PubMed]

276. Ibe, F.C.; Opara, A.I.; Ibe, B.O. Application of Pollution Risk Evaluation Models in Groundwater Systems in the Vicinity of Automobile Scrap Markets in Owerri Municipal and Environs, Southeastern Nigeria. Sci. Afr. 2020, 8, e00450. [CrossRef]

277. Atibu, E.K.; Lacroix, P.; Sivalingam, P.; Ray, N.; Giuliani, G.; Mulaji, C.K.; Otamonga, J.-P.; Mpiana, P.T.; Slaveykova, V.I.; Poté, J. High Contamination in the Areas Surrounding Abandoned Mines and Mining Activities: An Impact Assessment of the Dilala, Luilu and Mpingiri Rivers, Democratic Republic of the Congo. Chemosphere 2018, 191, 1008-1020. [CrossRef]

278. Mungai, T.M.; Wang, J. Heavy Metal Pollution in Suburban Topsoil of Nyeri, Kapsabet, Voi, Ngong and Juja Towns, in Kenya. SN Appl. Sci. 2019, 1, 960. [CrossRef]

279. Zhang, J.; Han, L.; Ji, Y.; Wei, J.; Cai, G.; Gao, G.; Wu, J.; Yao, Z. Heavy Metal Investigation and Risk Assessment along the Le'An River from Non-ferrous Metal Mining and Smelting Activities in Poyang, China. J. Environ. Biol. 2018, 39, 536-545. [CrossRef]

280. Adlane, B.; Xu, Z.; Xu, X.; Liang, L.; Han, J.; Qiu, G. Evaluation of the Potential Risks of Heavy Metal Contamination in Rice Paddy Soils Around an Abandoned Hg Mine Area in Southwest China. Acta Geochim. 2020, 39, 85-95. [CrossRef]

281. Bern, C.R.; Walton-Day, K.; Naftz, D.L. Improved Enrichment Factor Calculations through Principal Component Analysis: Examples from Soils near Breccia Pipe Uranium Mines, Arizona, USA. Environ. Pollut. 2019, 248, 90-100. [CrossRef]

282. Barbieri, M. The Importance of Enrichment Factor (EF) and Geoaccumulation Index (Igeo) to Evaluate the Soil Contamination. J. Geol. Geophys. 2016, 5, 1-4. [CrossRef] 
283. Hickey, C.W.; Clements, W.H. Effects of Heavy Metals on Benthic Macroinvertebrate Communities in New Zealand Streams. Environ. Toxicol. Chem. 1998, 17, 2338-2346. [CrossRef]

284. Decena, S.C.P.; Arguelles, M.S.; Robel, L.L. Assessing Heavy Metal Contamination in Surface Sediments in an Urban River in the Philippines. Polish J. Environ. Stud. 2018, 27, 1983-1995. [CrossRef]

285. Peng, S.; Dai, M.; Zhang, J.; Zhang, M.; Shi, Q.; Liang, B.; Zheng, T. Dynamics of Ecological Risks Associated with Heavy Metals in Sediments during the Construction Process of the Yangtze River Deepwater Channel. J. Clean. Prod. 2020, 269, 122231. [CrossRef]

286. Xu, Y.; Wu, Y.; Han, J.; Li, P. The Current Status of Heavy Metal in Lake Sediments from China: Pollution and Ecological Risk Assessment. Ecol. Evol. 2017, 7, 5454-5466. [CrossRef] [PubMed]

287. Enuneku, A.; Omoruyi, O.; Tongo, I.; Ogbomida, E.; Ogbeide, O.; Ezemonye, L. Evaluating the Potential Health Risks of Heavy Metal Pollution in Sediment and Selected Benthic Fauna of Benin River, Southern Nigeria. Appl. Water Sci. 2018, 8, 224. [CrossRef]

288. Yang, H.J.; Jeong, H.J.; Bong, K.M.; Jin, D.R.; Kang, T.-W.; Ryu, H.-S.; Han, J.H.; Yang, W.J.; Jung, H.; Hwang, S.H.; et al. Organic Matter and Heavy Metal in River Sediments of Southwestern Coastal Korea: Spatial Distributions, Pollution, and Ecological Risk Assessment. Mar. Pollut. Bull. 2020, 159, 111466. [CrossRef]

289. Utete, B.; Fregene, B.T. Assessing the Spatial and Temporal Variability and Related Environmental Risks of Toxic Metals in Lake Asejire, South-Western Nigeria. Sci. Afr. 2020, 7, e00259. [CrossRef]

290. Sakan, S.M.; Sakan, N.M.; Dordevic, D.S. Pollution characteristics and potential ecological risk assessment of heavy metals in river sediments based on calculation of pollution indices. In Advances in Environmental Research; Daniels, J.A., Ed.; Nova Science Publishers, Inc.: New York, USA, 2015; pp. 63-84.

291. Borgmann, U.; Norwood, W.P.; Reynoldson, T.B.; Rosa, F. Identifying Cause in Sediment Assessments: Bioavailability and the Sediment Quality Triad. Can. J. Fish. Aquat. Sci. 2001, 58, 950-960. [CrossRef]

292. Zheng, J.; Frey, H.C. Quantitative Analysis of Variability and Uncertainty with Known Measurement Error: Methodology and Case Study. Risk Anal. 2005, 25, 663-675. [CrossRef]

293. Dallas, H.F. Rapid Bioassessment Protocols Using Aquatic Macroinvertebrates in Africa-Considerations for Regional Adaptation of Existing Biotic Indices. Front. Water 2021, 3, 1-12. [CrossRef]

294. Barbour, M.T.; Gerritsen, J.; Snyder, B.D.; Stribling, J.B. Rapid Bioassessment Protocols for Use in Wadable Streams and Rivers: Periphyton, Benthic Macroinvertebrates, and Fish, 2nd ed.; USEPA: Washington, DC, USA, 1999.

295. Lowe, S.; Dallas, H.F.; Kennedy, M.; Taylor, J.; Gibbins, C.; Lang, P.; Sichingabula, H.; Saili, K.; Ntobolo, C.; Kabangu, K. SAFRASS Methodology Manual; University of Glasgow: Glasgow, Scotland, 2013.

296. Lang, P.; Taylor, J.C.; Bertolli, L.; Lowe, S.; Dallas, H.; Kennedy, M.P.; Gibbins, C.; Sichingabula, H.; Saili, K.; Day, J.; et al. Proposed Procedure for the Sampling, Preparation and Analysis of Benthic Diatoms from Zambian Rivers: A Bioassessment and Decision Support Tool Applicable to Freshwater Ecoregions in Tropical Southern Africa; East Kilbride, Scotland, 2013. Available online: https://www.academia.edu/27374366/SAFRASS_Proposed_procedure_for_the_sampling_preparation_and_analysis_of_ benthic_diatoms_from_Zambian_rivers_a_bioassessment_and_decision_support_tool_applicable_to_freshwater_ecoregions_ in_tropical_southern_Africa (accessed on 29 November 2021).

297. Elias, J.D. Simple and Cost-Effective Biomonitoring Method for Assessing Pollution in Tropical African Rivers. Open J. Ecol. 2021, 11, 407-436. [CrossRef]

298. Feio, M.J.; Hughes, R.M.; Callisto, M.; Nichols, S.J.; Odume, O.N.; Quintella, B.R.; Kuemmerlen, M.; Aguiar, F.C.; Almeida, S.F.P.; Alonso-EguíaLis, P.; et al. The Biological Assessment and Rehabilitation of the World's Rivers: An Overview. Water 2021, 13, 371. [CrossRef]

299. Chutter, F.M. The rapid biological assessment of streams and river water quality by means of macroinvertebrate communities in South Africa. Water research commission report N. In Classification of Rivers and Environmental Health Indicators; Uys, M.C., Ed.; Water Research Commission: Pretoria, South Africa, 1994; pp. 217-234.

300. Roux, D.J. Evaluation of the SASS2 Rapid Bioassessment Protocol for Assessing the Health of the Aquatic Environment: A Case Study on the Crocodile River, Eastern Transvaal; Department of Water Affairs and Forestry: Pretoria, South Africa, 1993.

301. Dallas, H.F. A Preliminary Evaluation of Aspects of SASS (South African Scoring System) for the Rapid Bioassessment of Water Quality in Rivers, with Particular Reference to the Incorporation of SASS in a National Biomonitoring Programme. S. Afr. J. Aquat. Sci. 1997, 23, 79-94. [CrossRef]

302. Dallas, H.F. An Evaluation of SASS (South African Scoring System) as a Tool for the Rapid Bioassessment of Water Quality. Master's Thesis, University of Cape Town, Cape Town, South Africa, 1995.

303. FRC Aquatic Biodiversity and Water Quality of the Okavango Delta and Wetland Monitoring of the Okavango Delta, Botswana, Using Aquatic Macroinvertebrates. Available online: http:/ / frcsa.org.za/monitoring-management/okavango-delta/ (accessed on 4 October 2021).

304. Dallas, H.; Mosepele, B. Spatial Variability of Aquatic Macroinvertebrate Assemblages in the Okavango Delta, Botswana: Considerations for Developing a Rapid Bioassessment Tool. Afr. J. Aquat. Sci. 2020, 350-363. [CrossRef]

305. Jones, F.C. Taxonomic Sufficiency: The Influence of Taxonomic Resolution on Freshwater Bioassessments Using Benthic Macroinvertebrates. Environ. Rev. 2008, 16, 45-69. [CrossRef]

306. Bere, T.; Mangadze, T.; Mwedzi, T. The Application and Testing of Diatom-based Indices of Stream Water Quality in Chinhoyi Town, Zimbabwe. Water SA 2014, 40, 503-512. [CrossRef] 
307. Bere, T.; Nyamupingidza, B.B. Use of Biological Monitoring Tools Beyond their Country of Origin: A case study of the South African Scoring System Version 5 (SASS5). Hydrobiologia 2014, 722, 223-232. [CrossRef]

308. Bere, T.; Dalu, T.; Mwedzi, T. Detecting the Impact of Heavy Metal Contaminated Sediment on Benthic Macroinvertebrate Communities in Tropical Streams. Sci. Total Environ. 2016, 572, 147-156. [CrossRef]

309. Pawlowski, J.; Kelly-Quinn, M.; Altermatt, F.; Apothéloz-Perret-Gentil, L.; Beja, P.; Boggero, A.; Borja, A.; Bouchez, A.; Cordier, T.; Domaizon, I.; et al. The Future of Biotic Indices in the Ecogenomic Era: Integrating (e)DNA Metabarcoding in Biological Assessment of Aquatic Ecosystems. Sci. Total Environ. 2018, 637-638, 1295-1310. [CrossRef]

310. Pawlowski, J.; Apothéloz-Perret-Gentil, L.; Mächler, E.; Altermatt, F. Environmental DNA Applications in Biomonitoring and Bioassessment of Aquatic Ecosystems: Guidelines; Federal Office for the Environment (FOEN): Bern, Switzerland, 2020.

311. Elbrecht, V.; Peinert, B.; Leese, F. Sorting Things Out: Assessing Effects of Unequal Specimen Biomass on DNA Metabarcoding. Ecol. Evol. 2017, 7, 6918-6926. [CrossRef] [PubMed]

312. Weigand, A.; Bouchez, A.; Boets, P.; Bruce, K.; Ciampor, F.; Ekrem, T.; Fontaneto, D.; Franc, A.; Hering, D.; Kahlert, M.; et al. Taming the Wild West of Molecular Tools Application in Aquatic Research and Biomonitoring. Biodivers. Inf. Sci. Stand. 2019, 3, e37215. [CrossRef]

313. Rattanachan, N.; Boonsoong, B.; Getwongsa, P.; Uttaruk, Y.; Sangpradub, N. A Benthic Macroinvertebrate Multimetric Index for Assessment of the Ecological Integrity of Northeast Streams, Thailand. EnvironmentAsia 2016, 9, 186-194. [CrossRef] 